\title{
Two new species of Echinoderes (Kinorhyncha: Cyclorhagida) from the Gulf of Mexico
}

\author{
Martin V. Sørensen ${ }^{1 *}$ and Stephen C. Landers ${ }^{2}$ \\ ' Geogenetics, Natural History Museum of Denmark, University of Copenhagen, Copenhagen, Denmark \\ ${ }^{2}$ Department of Biological and Environmental Sciences, Troy University, Troy, AL, USA
}

\author{
Edited by: \\ Tito Monteiro Da Cruz Lotufo, \\ Universidade Federal do Ceara, \\ Brazil \\ Reviewed by: \\ Fernando Pardos, Universidad \\ Complutense de Madrid, Spain \\ Maikon Di Domenico, University of \\ Campinas, Brazil

\section{*Correspondence:} \\ Martin V. Sorensen, Oster Voldgade \\ 5-7, 1350 Copenhagen K, Denmark \\ e-mail:mvsorensen@snm.ku.dk
}

Comprehensive sampling of meiofauna along the northern continental slope in the Gulf of Mexico has revealed a diverse kinorhynch fauna of undescribed species. The present contribution includes the description of two new species of the cyclorhagid genus Echinoderes. Echinoderes augustae sp. nov. is recognized by the presence of acicular spines in middorsal positions on segments $4-8$, and in lateroventral positions on segments $6-9$, tubes in lateroventral positions on segments $2-5$, midlateral positions on segment 4 , and in sublateral positions on segment 8 . It furthermore has glandular cell outlets type 2 in subdorsal positions of segment 2, a middorsal protuberance-like extension from the intersegmental border between segments 10 and 11, and conspicuously short and stout lateral terminal spines. Echinoderes skipperae sp. nov. has acicular spines in middorsal positions on segments 4, 6, and 8, and in lateroventral positions on segments 8 and 9 , tubes in sublateral and ventrolateral positions on segment 2, in lateroventral positions on segment 5 , in lateral accessory positions on segment 8 , and in laterodorsal positions on segment 10 . The species can furthermore be recognized by its conspicuously well-developed pachycycli at the anterior segment margins of segments 2 to 10, and margins of sternal plates facing the midsternal junctions of segments 3 to 10 .

Keywords: Echinoderidae, kinorhynchs, meiofauna, morphology, taxonomy

\section{INTRODUCTION}

The meiobenthic invertebrate group Kinorhyncha can be found in the oceans throughout the world, but even though these animals have been known for more than 150 years, only slightly more than 200 species are described today, and sampling efforts to obtain more information about their biodiversity have been scattered and random, to say the least. The US East Coast is considered as relatively well-sampled, primarily due to the efforts of Robert P. Higgins (Higgins, 1964a,b, 1965, 1977, 1990; Higgins and Fleeger, 1980), as well as other more recent initiatives (Sørensen, 2007; Sørensen et al., 2005, 2007; Herranz and Pardos, 2013; Herranz et al., 2014), but even in this regard, the sampling areas have to a great extent been determined by location of field stations and coincident sampling opportunities. More coordinated sampling, with a focus on the kinorhynch fauna and distribution specifically, has within the last two decades been carried out in the waters around in the Iberian Peninsula in Southwest Europe (Pardos et al., 1998; Ga Ordóñez et al., 2008; Sánchez et al., 2011, 2012, 2014; Herranz et al., 2012; Sørensen et al., 2012a). This work has extended our knowledge about kinorhynch diversity significantly, and at the taxonomic level it has been a major contribution. However, despite the numerous samplings and hours spend analyzing the results, the information is still too incomplete to point out any general patterns in the kinorhynch community structures, species distribution, sediment preferences, etc. An almost parallel example can be found in a third rather well-examined region, namely the waters around the Korean Peninsula. Through a series of recent contributions our knowledge about the East Asian kinorhynch fauna has increased greatly (Sørensen et al., 2010a,b,c, 2012a,b, 2013; Lundbye et al., 2011; Sánchez et al., 2013; Thomsen et al., 2013), but a closer examination of the recordings of each species leaves no clear picture about their actual distributional ranges or eventual habitat preferences.

Currently, our information about the Gulf of Mexico kinorhynch fauna is extremely scarce, and limited to a single published recording by Chitwood (1951), who reports the finding of Echinoderes steineri from Aransas Bay near Corpus Christi, Texas. Shirley (2009) furthermore cites a personal communication of John Fleeger, who reports the finding of an Echinoderes species resembling Echinoderes coulli at near-shore localities in Louisiana. In 2007 an extensive meiofauna survey was initiated in the northern Gulf of Mexico (Landers et al., 2012). From 2007-2009 meiofauna were collected on National Ocean and Atmospheric Administration (NOAA) research vessels along the United States' continental shelf from Mexico to the Florida Keys. Following the Deepwater Horizon oil spill disaster in 2010, this research has received funding from the Gulf of Mexico Research Initiative (GoMRI) to continue the meiobenthic surveys in the Northern Gulf. Currently the collections have resulted in hundreds of meiobenthic samples and have provided a unique opportunity to get detailed information about the meiofaunal and specifically kinorhynch communities along the rim of the continental shelf.

The present study is the first in a series of contributions that focuses on the kinorhynch fauna collected during the NOAA cruises beginning in 2007. Currently about 22 different species-most of them new to science-have been identified. Even though sampling continues, we have now sufficient 
information to present the first results of the taxonomic studies, and in the following we are describing two of the more abundant species. The new taxa belong to the specious genus Echinoderes. Both of them are highly characteristic in their morphology, which makes them easy to recognize, even for the non-specialist.

\section{MATERIALS AND METHODS}

Samples were collected from 2007 to 2012 on the NOAA ships Gordon Gunter and Pisces, in conjunction with the National Marine Fisheries Service Laboratory in Pascagoula, Mississippi. Specimens for the present study originate from 16 stations distributed across the United States' Gulf of Mexico continental shelf (see Figure 1 and Table 1 for details about sampling and positions). Sediment samples were collected using a box corer (WildCo®) ) or a Shipek ${ }^{\circledR}$ sediment grab.

The samples were fixed immediately in $5-10 \%$ formalin, and kinorhynchs were subsequently extracted by Ludox centrifugation (Burgess, 2001). After sorting under a dissecting microscope, the specimens were stored in isopropanol until prepared for light microscopy (LM) or scanning electron microscopy (SEM) examination. Specimens for LM were dehydrated through a graded series of glycerin, mounted in Fluoromount G, mounted between two cover glasses and attached to a plastic H-S slide with glyceel. They were examined and photographed with an Olympus BX51 microscope, equipped with an Olympus DP20 camera and a drawing tube. Line art illustrations were based on camera lucida drafts of mounted specimens that subsequently were scanned and drawn in Adobe Illustrator CS5. Measurements were made with $\mathrm{Cell}^{\wedge} \mathrm{D}$ software. All dimensions reported in the tables are based on LM measurements. If a dimension mentioned in the text is estimated from SEM images, this is indicated clearly. Specimens for SEM were primarily examined in Copenhagen, and were dehydrated through a series of alcohol, critical point dried, mounted on aluminum stubs, sputter coated with a platinum/palladium mix, and examined with a JEOL JSM-6335F Field Emission scanning electron microscope.
The type material is deposited at the Natural History Museum of Denmark and at the Smithsonian Institution, National Museum of Natural History. Even though it has been common practice up to now, allotypes are not designated, because they do not have a name-bearing function according to the International Code of Zoological Nomenclature (see ICZN, 1999).

\section{SYSTEMATICS}

Order Cyclorhagida Zelinka, 1896

Family Echinoderidae Bütschli, 1876

Genus Echinoderes Claparède, 1863

\section{ECHINODERES AUGUSTAE SP. NOV. Type material}

Holotype, adult female, collected from mud on October 25, 2012, at station 084 (Figure 1), at $85 \mathrm{~m}$ depth near the rim of the continental Shelf, east of the Mississippi River Delta $\left(28^{\circ} 58^{\prime} 51.02^{\prime \prime} \mathrm{N}\right.$ $\left.088^{\circ} 59^{\prime} 56.47^{\prime \prime} \mathrm{W}\right)$, mounted in Fluoromount G, deposited at the Natural History Museum of Denmark, under accession number ZMUC KIN-705. Paratypes include nine specimens mounted in Fluoromount G (seven specimens deposited at the Natural History Museum of Denmark under accession numbers ZMUC KIN-706 to KIN-712, and two specimens deposited at the Smithsonian Institution, National Museum of Natural History under accession numbers USNM 1231476-1231477) and 16 specimens mounted for SEM (accession numbers ZMUC KIN-713 to KIN-729), deposited at the Natural History Museum of Denmark. Paratypes originate from eight stations near the rim of the continental shelf, from site 033 in the west (southeast of Galveston, Texas) to site 163 in the east (southwest of Tampa, Florida). The species was furthermore recorded from four additional stations, but these specimens were either lost, had incomplete collection information or are included in S. Landers' personal reference collection. See Figure 1 for localities and Table 1 for detailed station data.

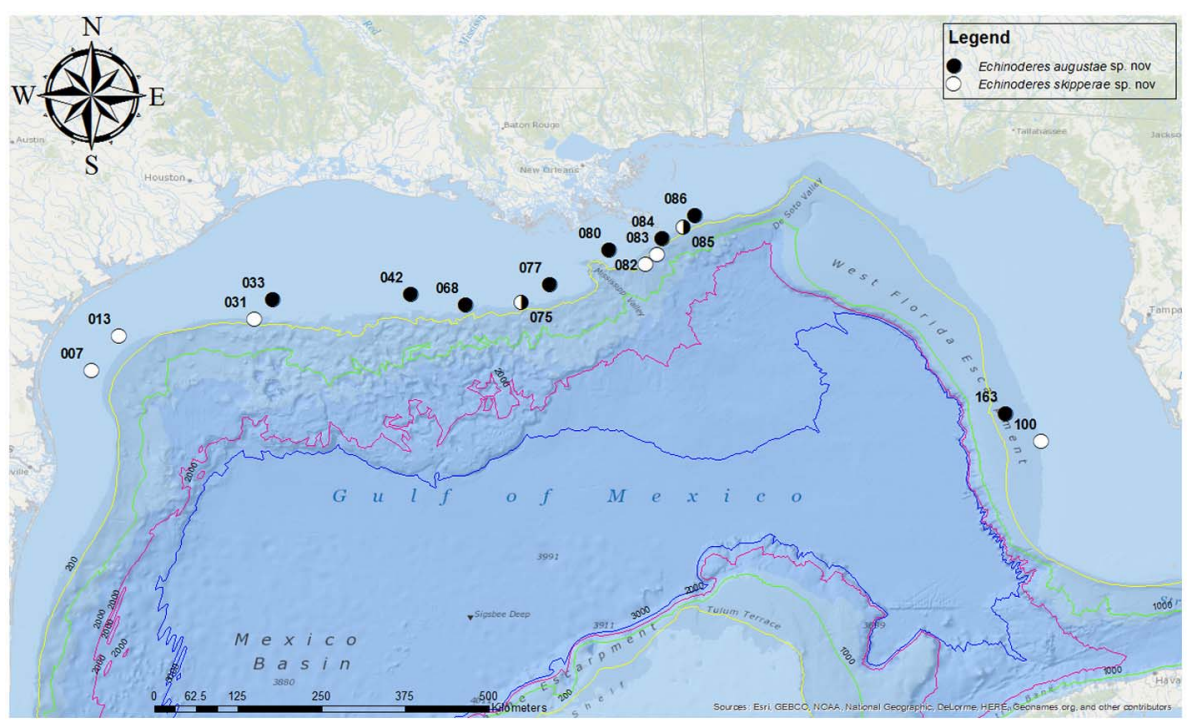

FIGURE 1 | Map showing the sampling locations in the Gulf of Mexico. Station numbers are given for each collection site. 
Table 1 | Summary of data on stations, species identities, and accession numbers.

\begin{tabular}{|c|c|c|c|c|c|c|}
\hline Date & Station & Position & Depth & Species & Mounting & $\begin{array}{l}\text { Type status and accession } \\
\text { numbers }\end{array}$ \\
\hline Nov. 9, 2008 & 163 & $\begin{array}{l}26^{\circ} 37^{\prime} 40.55^{\prime \prime} \mathrm{N} \\
84^{\circ} 22^{\prime} 49.33^{\prime \prime} \mathrm{W} \\
\left(26.62793^{\circ},-84.38037^{\circ}\right)\end{array}$ & $178 m$ & $\begin{array}{l}\text { Echinoderes augustae } \\
\text { sp. nov. }\end{array}$ & SEM & Non-type in Landers collection \\
\hline Oct. 21, 2011 & 033 & $\begin{array}{l}28^{\circ} 09^{\prime} 50.90^{\prime \prime} \mathrm{N} \\
94^{\circ} 14^{\prime} 26.23^{\prime \prime} \mathrm{W} \\
\left(28.16414^{\circ},-94.24062^{\circ}\right)\end{array}$ & $56 m$ & $\begin{array}{l}\text { Echinoderes augustae } \\
\text { sp. nov. }\end{array}$ & SEM & $10^{7}$ paratype: KIN-713 \\
\hline Oct. 22, 2011 & 042 & $\begin{array}{l}28^{\circ} 14^{\prime} 14.17^{\prime \prime} \mathrm{N} \\
92^{\circ} 22^{\prime} 34.72^{\prime \prime} \mathrm{W} \\
\left(28.23727^{\circ},-92.37631^{\circ}\right)\end{array}$ & $64 m$ & $\begin{array}{l}\text { Echinoderes augustae } \\
\text { sp. nov. }\end{array}$ & - & Specimen lost during preparation \\
\hline Oct. 22, 2012 & 068 & $\begin{array}{l}28^{\circ} 05^{\prime} 12.52^{\prime \prime} \mathrm{N} \\
91^{\circ} 38^{\prime} 12.62^{\prime \prime} \mathrm{W} \\
\left(28.08681^{\circ},-91.63684^{\circ}\right)\end{array}$ & $102 \mathrm{~m}$ & $\begin{array}{l}\text { Echinoderes augustae } \\
\text { sp. nov. }\end{array}$ & LM & 1 q paratype: KIN-711 \\
\hline Oct. 24, 2012 & 077 & $\begin{array}{l}28^{\circ} 22^{\prime} 07.50^{\prime \prime} \mathrm{N} \\
90^{\circ} 30^{\prime} 44.06^{\prime \prime} \mathrm{W} \\
\left(28.36875^{\circ},-90.51224^{\circ}\right)\end{array}$ & $49 m$ & $\begin{array}{l}\text { Echinoderes augustae } \\
\text { sp. nov. }\end{array}$ & SEM & $\begin{array}{l}3 \text { o paratypes: KIN-717 to } \\
\text { KIN-719; } 1 \text { ơ paratype: KIN-720 }\end{array}$ \\
\hline Oct. 24, 2012 & 080 & $\begin{array}{l}28^{\circ} 49^{\prime} 22.76^{\prime \prime} \mathrm{N} \\
89^{\circ} 42^{\prime} 38.63^{\prime \prime} \mathrm{W} \\
\left(28.82299^{\circ},-89.71073^{\circ}\right)\end{array}$ & $70 \mathrm{~m}$ & $\begin{array}{l}\text { Echinoderes augustae } \\
\text { sp. nov. }\end{array}$ & LM & $\begin{array}{l}1 \sigma^{7} \text { paratype (mounted laterally): } \\
\text { KIN-712 }\end{array}$ \\
\hline Oct. 25, 2012 & 084 & $\begin{array}{l}28^{\circ} 58^{\prime} 51.02^{\prime \prime} \mathrm{N} \\
88^{\circ} 59^{\prime} 56.47^{\prime \prime} \mathrm{W} \\
\left(28.98084^{\circ},-88.99902^{\circ}\right)\end{array}$ & $85 \mathrm{~m}$ & $\begin{array}{l}\text { Echinoderes augustae } \\
\text { sp. nov. }\end{array}$ & $\begin{array}{l}\text { LM } \\
\text { SEM }\end{array}$ & $\begin{array}{l}\text { o holotype: KIN-705; } 1 \text { \% } \\
\text { paratype: KIN-706 } \\
3 \text { q paratypes: KIN-721 to KIN-723 }\end{array}$ \\
\hline Oct. 25, 2012 & 086 & $\begin{array}{l}29^{\circ} 17^{\prime} 21.16^{\prime \prime} \mathrm{N} \\
88^{\circ} 33^{\prime} 21.24^{\prime \prime} \mathrm{W} \\
\left(29.28921^{\circ},-88.55590^{\circ}\right)\end{array}$ & $66 \mathrm{~m}$ & $\begin{array}{l}\text { Echinoderes augustae } \\
\text { sp. nov. }\end{array}$ & $\begin{array}{l}\text { LM } \\
\text { SEM }\end{array}$ & $\begin{array}{l}3 \text { o paratypes: KIN-707 to } \\
\text { KIN-709; } 1 \text { o }^{7} \text { paratype: KIN-710 } \\
1 \text { \& paratype: KIN-729; } 1 \sigma^{7} \\
\text { paratype: KIN-728 }\end{array}$ \\
\hline Oct. 15, 2010 & 007 & 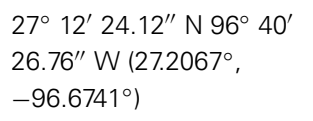 & $72 m$ & $\begin{array}{l}\text { Echinoderes skipperae } \\
\text { sp. nov. }\end{array}$ & LM & $\begin{array}{l}2 \text { o paratypes: KIN-731, KIN-732; } \\
1 \text { o }^{7} \text { paratype (broken): KIN-733 }\end{array}$ \\
\hline Oct. 17, 2010 & 013 & $\begin{array}{l}27^{\circ} 40^{\prime} 07.32^{\prime \prime} \mathrm{N} \\
96^{\circ} 18^{\prime} 48.24^{\prime \prime} \mathrm{W} \\
\left(27.6687^{\circ},-96.3134^{\circ}\right)\end{array}$ & $73 m$ & $\begin{array}{l}\text { Echinoderes skipperae } \\
\text { sp. nov. }\end{array}$ & LM & $10^{\top}$ paratype: USNM-1231478 \\
\hline Oct. 20, 2010 & 031 & $\begin{array}{l}27^{0} 54^{\prime} 12.60^{\prime \prime} \mathrm{N} \\
94^{\circ} 28^{\prime} 50.88^{\prime \prime} \mathrm{W} \\
\left(27.9035^{\circ},-94.4808^{\circ}\right)\end{array}$ & $135 \mathrm{~m}$ & $\begin{array}{l}\text { Echinoderes skipperae } \\
\text { sp. nov. }\end{array}$ & LM & $\begin{array}{l}1 \text { o paratype: USNM-1231479; } 1 \\
\text { damaged paratype: KIN-734 }\end{array}$ \\
\hline Nov. 10, 2010 & 100 & $\begin{array}{l}26^{\circ} 15^{\prime} 44.28^{\prime \prime}{\mathrm{N} 83^{\circ}}^{\circ} 53^{\prime} \\
56.04^{\prime \prime} \mathrm{W}\left(26.2623^{\circ}\right. \\
\left.-83.8989^{\circ}\right)\end{array}$ & $110 \mathrm{~m}$ & $\begin{array}{l}\text { Echinoderes skipperae } \\
\text { sp. nov. }\end{array}$ & LM & 1 paratype (broken): KIN-735 \\
\hline
\end{tabular}


Table 1 | Continued

\begin{tabular}{|c|c|c|c|c|c|c|}
\hline Date & Station & Position & Depth & Species & Mounting & $\begin{array}{l}\text { Type status and accession } \\
\text { numbers }\end{array}$ \\
\hline Oct. 23, 2012 & 075 & $\begin{array}{l}28^{\circ} 07^{\prime} 28.49^{\prime \prime} \mathrm{N} \\
90^{\circ} 53^{\prime} 37.32^{\prime \prime} \mathrm{W} \\
\left(28.12458^{\circ},-90.89370^{\circ}\right)\end{array}$ & $113 m$ & $\begin{array}{l}\text { Echinoderes skipperae } \\
\text { sp. nov. }\end{array}$ & LM & 1 q paratype: KIN-736 \\
\hline Oct. 25, 2012 & 082 & $\begin{array}{l}28^{\circ} 37^{\prime} 59.34^{\prime \prime} \mathrm{N} \\
89^{\circ} 13^{\prime} 16.32^{\prime \prime} \mathrm{W} \\
\left(28.63315^{\circ},-89.22120^{\circ}\right)\end{array}$ & $242 m$ & $\begin{array}{l}\text { Echinoderes skipperae } \\
\text { sp. nov. }\end{array}$ & SEM & $10^{7}$ paratype: KIN-739 \\
\hline Oct. 25, 2012 & 083 & $\begin{array}{l}28^{\circ} 46^{\prime} 27.19^{\prime \prime} \mathrm{N} \\
89^{\circ} 04^{\prime} 30.18^{\prime \prime} \mathrm{W} \\
\left(28.77422^{\circ},-89.07505^{\circ}\right)\end{array}$ & $361 \mathrm{~m}$ & $\begin{array}{l}\text { Echinoderes skipperae } \\
\text { sp. nov. }\end{array}$ & LM & $10^{\pi}$ paratype: KIN-737 \\
\hline Oct. 25, 2012 & 085 & $\begin{array}{l}29^{\circ} 07^{\prime} 56.71^{\prime \prime} \mathrm{N} \\
88^{\circ} 42^{\prime} 27.47^{\prime \prime} \mathrm{W} \\
\left(29.13242^{\circ},-88.70763^{\circ}\right)\end{array}$ & $86 m$ & $\begin{array}{l}\text { Echinoderes skipperae } \\
\text { sp. nov. }\end{array}$ & $\begin{array}{l}\text { LM } \\
\text { SEM }\end{array}$ & $\begin{array}{l}\text { o holotype: KIN-730; } 1 \text { } \\
\text { paratype: KIN-738 } \\
2 \text { q paratypes: KIN-740, KIN-741; } 1 \\
\sigma^{7} \text { paratype: KIN-742 }\end{array}$ \\
\hline
\end{tabular}

\section{Diagnosis}

Echinoderes with acicular spines in middorsal positions on segments 4 to 8 , and in lateroventral positions on segments 6 to 9. Tubes present in lateroventral positions on segments 2 and 5 , midlateral positions on segment 4 , and in sublateral positions on segment 8; males furthermore with tubes in laterodorsal positions on segment 10. Large glandular cell outlets type 2 in subdorsal positions of segment 2 . A conspicuous middorsal protuberancelike structure extends from the intersegmental border between segments 10 and 11. Tergal extensions of segment 11 short and triangular. Lateral terminal spines conspicuously short and stout. Males with three penile spines, females with short, and thin lateral terminal accessory spines.

\section{Etymology}

The species is named after Augusta Bork Larsen in appreciation of her help and assistance examining the new species.

\section{Description}

Adults with head, neck, and 11 trunk segments (Figures 2A,B, $4 A, F, 5 A)$. The trunk of the species appears relatively broad and stout in its anterior end, but tapers from segment 7 toward its much slimmer hind end. Its lateral terminal spines appear conspicuously short and stout. For complete overview of measures and dimensions, see Table 2. Distribution of cuticular structures, i.e., sensory spots, glandular cell outlets, spines and tubes, is summarized in Table 3.

The head consists of a retractable mouth cone and an introvert (Figures 3, 5B,C). The pharynx terminates into a pharyngeal crown, and rings of inner oral styles are present, but their exact number and arrangement could not be determined. The external mouth cone armature consists of nine outer oral styles that alternate in size between slightly smaller and slightly larger ones (Figure 5B), arranged as one style anterior to each introvert sector, except the middorsal sector 6 (Figure 3). A structure with laterally folded margins is located at the base of each style. The structure has three distally bifurcated spikes located at its base, and a pair of lateral spikes that insert more anterior (Figure 5B). More posterior on the mouth cone, large elongated diamondshaped elements are present in between the bases of each of the outer oral styles. Each element has a basal fringe with short, densely set fringe tips. Posterior to introvert sector 6, where the style is missing, the element is triangular, rather than diamondshaped, and the tips in the median part of the fringe are considerably longer and extend almost to the tip of the triangle (Figure 5B).

The introvert sectors are defined by 10 primary spinoscalids in Ring 01 (Figure 3). Each primary spinoscalid consists of a basal sheath and a distal end piece with a blunt tip (Figure 5C). The basal sheaths have several long extensions that form transverse fringes, whereas the end pieces vary between some smooth parts, and some parts with longitudinal wrinkles. Rings 02 and 04 have 10 spinoscalids and Ring 03 has 20 (Figure 3). All spinoscalids in these rings consist of a basal sheath and an end piece. The basal sheaths terminate into fringed margins. Ring 03 spinoscalids furthermore have a median spike anterior to their attachment points (Figure 5C). Ring 05 has 20 spinoscalids that are composed as those in the preceding rings, but with shorter end pieces though. A ring of short fringes appear to extend around the introvert in between spinoscalid rings 04 and 05 (Figure 5C). Rings 06 and 07 have only 6 spinoscalids each (Figure 3). These scalids are considerably shorter than those in the more anterior rings, their basal sheaths have serrulated margins, and the end pieces are wrinkled. Additional scalids are found even more posterior on the introvert. These scalids are very short and appears to consist of partly fused fringe-like extensions, leaving the impression that they might be reduced trichoscalids, even though they do not attach to a trichoscalid plate (Figures 5C,D). These putative reduced trichoscalids are located in sections 3, 5, 6,7 , and 9 (Figure 3). It was not possible to confirm the eventual presence of a similar reduced trichoscalid in section 1 , but its presence would be expected from the general symmetry patterns in the introvert. Well-developed trichoscalids, attached to trichoscalid plates, are present in sectors $2,4,5,7,8$, and 10 
A

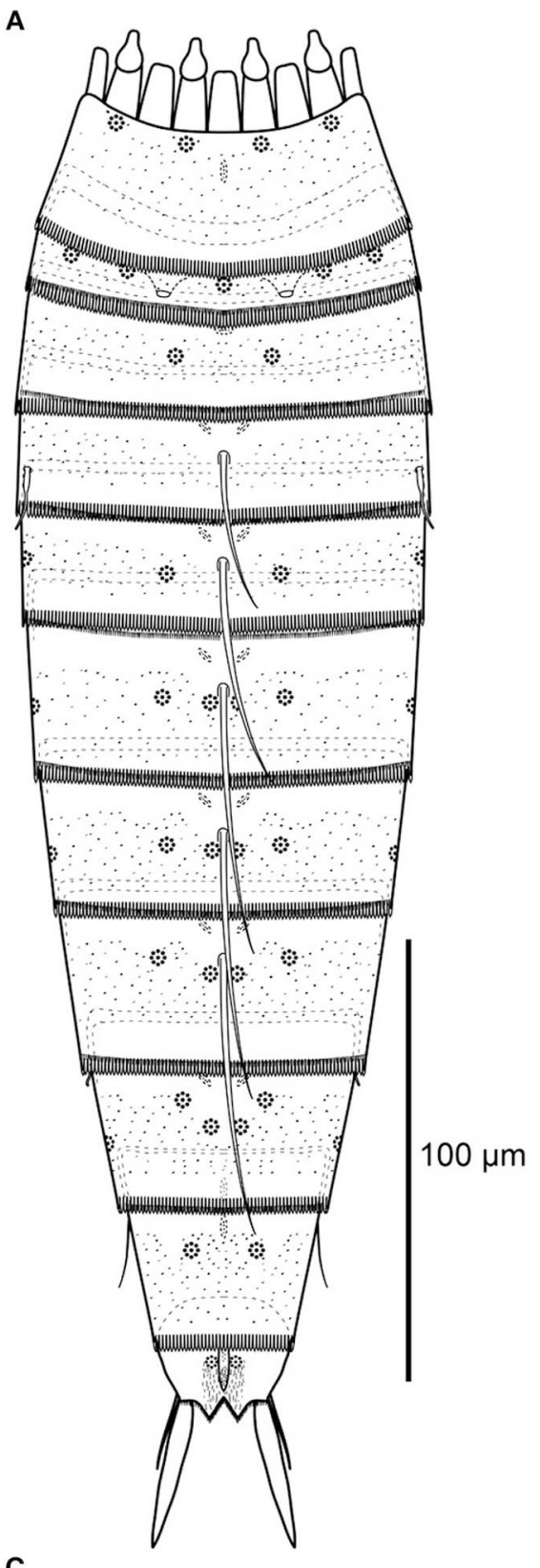

C

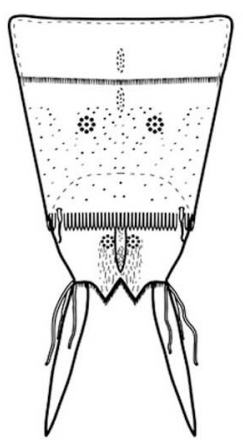

B
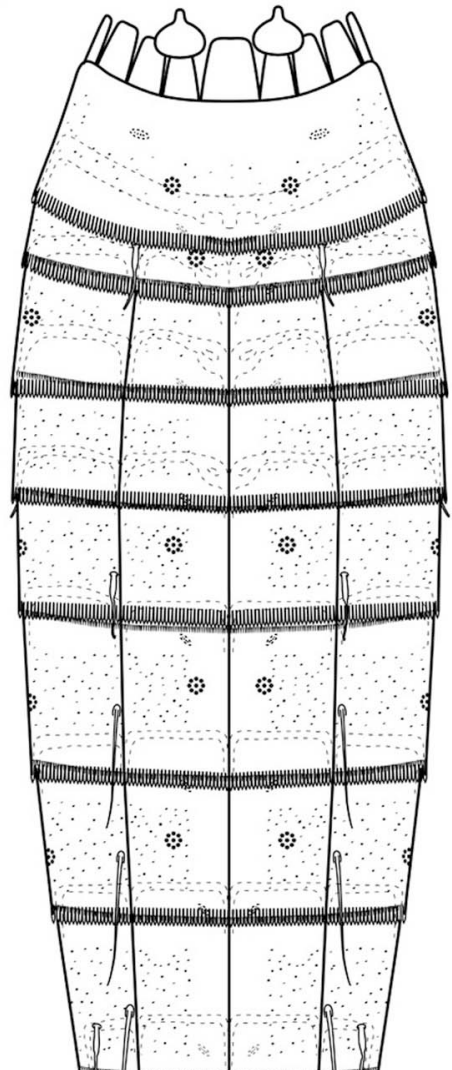

and
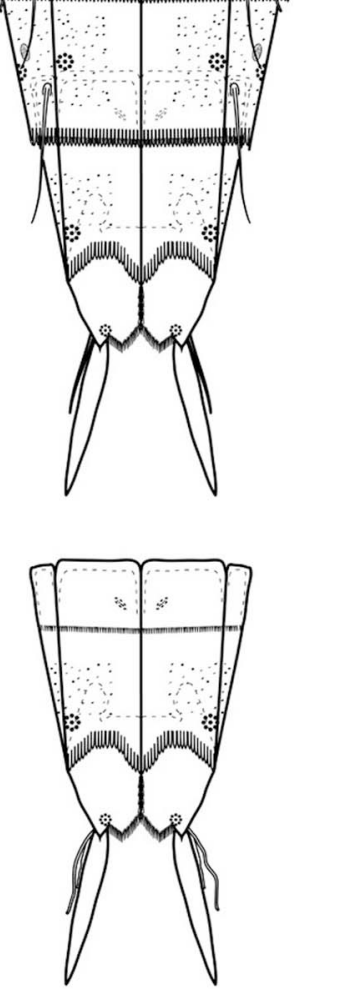

FIGURE 2 | Line art illustrations of Echinoderes augustae sp. nov. (A) Female, dorsal view. (B) Female, ventral view. (C) Male, segments 10 to 11, dorsal view. (D) Male, segments 10 to 11, ventral view. 
Table 2 | Measurements from light microscopy of adult Echinoderes augustae sp. nov. (in $\mu \mathrm{m}$ ), including number of measured specimens $(n)$, and standard deviation (SD).

\begin{tabular}{|c|c|c|c|c|}
\hline Character & $n$ & Range & Mean & $S D$ \\
\hline $\mathrm{TL}$ & 11 & $258-354$ & 298 & 31.68 \\
\hline MSW-6 & 10 & $47-56$ & 51 & 2.84 \\
\hline MSW-6/TL & 10 & $15.5-19.8 \%$ & $17.2 \%$ & $1.60 \%$ \\
\hline SW-10 & 10 & $37-43$ & 41 & 1.91 \\
\hline SW-10/TL & 10 & $11.9-16.7 \%$ & $13.8 \%$ & $1.49 \%$ \\
\hline $\mathrm{S} 1$ & 11 & 29-35 & 31 & 2.05 \\
\hline S2 & 11 & $30-37$ & 33 & 2.40 \\
\hline S3 & 11 & $29-40$ & 34 & 3.33 \\
\hline S4 & 11 & $30-41$ & 35 & 4.04 \\
\hline S5 & 11 & $31-46$ & 37 & 4.44 \\
\hline S6 & 11 & 33-48 & 40 & 4.64 \\
\hline S7 & 11 & $38-50$ & 42 & 3.34 \\
\hline S8 & 11 & $40-50$ & 44 & 2.88 \\
\hline S9 & 11 & $42-48$ & 45 & 1.81 \\
\hline S10 & 11 & $41-53$ & 47 & 3.70 \\
\hline S11 & 10 & 22-33 & 30 & 3.57 \\
\hline MD4 & 10 & $30-34$ & 32 & 1.56 \\
\hline MD5 & 10 & $39-53$ & 46 & 4.97 \\
\hline MD6 & 9 & $37-58$ & 50 & 7.52 \\
\hline MD7 & 9 & $44-63$ & 57 & 6.33 \\
\hline MD8 & 10 & $51-74$ & 60 & 6.23 \\
\hline LV6 & 11 & $15-28$ & 23 & 4.23 \\
\hline LV7 & 11 & $18-30$ & 26 & 3.66 \\
\hline LV8 & 11 & $25-37$ & 29 & 3.74 \\
\hline LV9 & 11 & $19-30$ & 24 & 3.25 \\
\hline LTS & 11 & $31-44$ & 34 & 3.79 \\
\hline LTASo & 7 & 10-22 & 17 & 3.73 \\
\hline LTS/TL & 11 & $9.9-12.9 \%$ & $11.4 \%$ & $0.92 \%$ \\
\hline
\end{tabular}

Abbreviations: MD, middorsal spine; LTAS, lateral terminal accessory spine; LTS, lateral terminal spine; $L V$, lateroventral spine; MSW-6, maximum sternal width, measured on segment 6 in this species; S, segment lengths; SW-10, standard width, always measured on segment 10; TL, trunk length.
(Figures 3, 4B, 5C). Described sector-wise, sectors 1 and 6 are similar, having spinoscalids arranged as two double diamonds (the only difference between the sections is the reduced trichoscalid, present posteriorly in section 6 but with its presence unconfirmed for section 1). Sectors 2, 4, 8, and 10 all have spinoscalids arranged as a quincunx, located in between a medial anterior spinoscalid and a trichoscalid plate. The remaining sectors, $3,5,7$, and 9 are almost identical, having a set of double diamonds located anterior to a pair of Ring 07 spinoscalids and a pair of reduced trichoscalids. However, in sectors 5 and 7, one Ring 07 spinoscalid and one reduced trichoscalid are missing, due to the presence of a trichoscalid plate that takes up space (Figure 3).

The neck has 16 placids, measuring $11 \mu \mathrm{m}$ in length. The midventral placid is broadest (Figures 2B, 4C), measuring $13 \mu \mathrm{m}$ in width at its base, whereas all other are narrower (Figures 2A, 4B), measuring $7 \mu \mathrm{m}$ in width at their bases. The trichoscalid plates are well-developed, with the ventral pair (Figure 4C) being broader $(13 \mu \mathrm{m}$ in width) than the two dorsal pairs ( $8 \mu \mathrm{m}$ in width) (Figure 4B).

Segment 1 consists of a complete cuticular ring (Figures 2A,B, 4A-C,F, 5A,E). Sensory spots are located near the anterior segment margin in subdorsal and laterodorsal positions (Figure 5E), and more posteriorly in ventromedial positions (Figure 2B). The sensory spots are small and rounded. Glandular cell outlets type 1 are present in middorsal and lateroventral positions (Figures 2A,B, 4B). In light microscopy the subcuticular glandular cells appear like a row of light refracting granules (Figure 4B). The light refracting granules are arranged as a vertical row in the middorsal position, whereas those in the lateroventral positions form transverse rows. Cuticular hairs emerge through rounded perforation sites, and are scattered around the segment. On the dorsal side (Figure 5E), the hairy area extends to a position just posterior to the sensory spots, whereas the anterior half of the segment is without hair on the ventral side. Posteriorly,

Table 3 | Summary of nature and location of sensory spots, glandular cell outlets, tubes and spines arranged by series in Echinoderes augustae sp. nov.

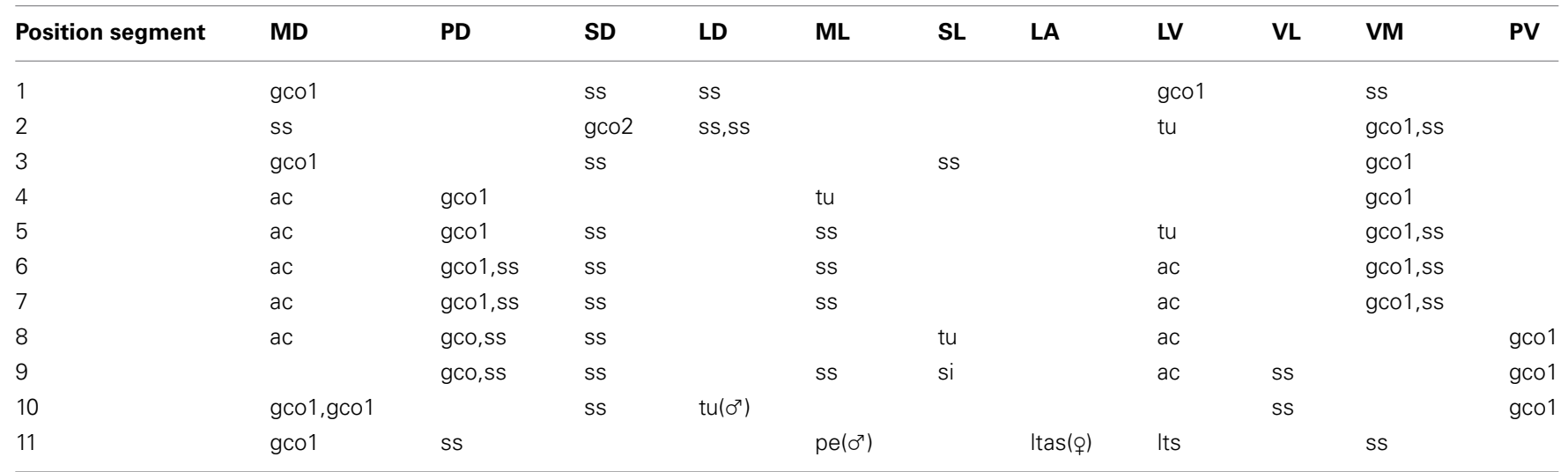

Abbreviations: $L A$, lateral accessory; $L D$, Laterodorsal; $L V$, lateroventral; $M D$, middorsal; $M L$, midlateral; $P D$, paradorsal; $P V$, paraventral; $S D$, subdorsal; $S L$, sublateral; $V L$, ventrolateral; VM, ventromedial; ac, acicular spine; (o), female condition of sexual dimorphic character; gco 1/2, glandular cell outlet type 1/2; Itas, lateral terminal accessory spine; Its, lateral terminal spine; $\left(0^{\top}\right)$, male condition of sexual dimorphic character; pe, penile spines; si, sieve plate; ss, sensory spot; tu, tube. 


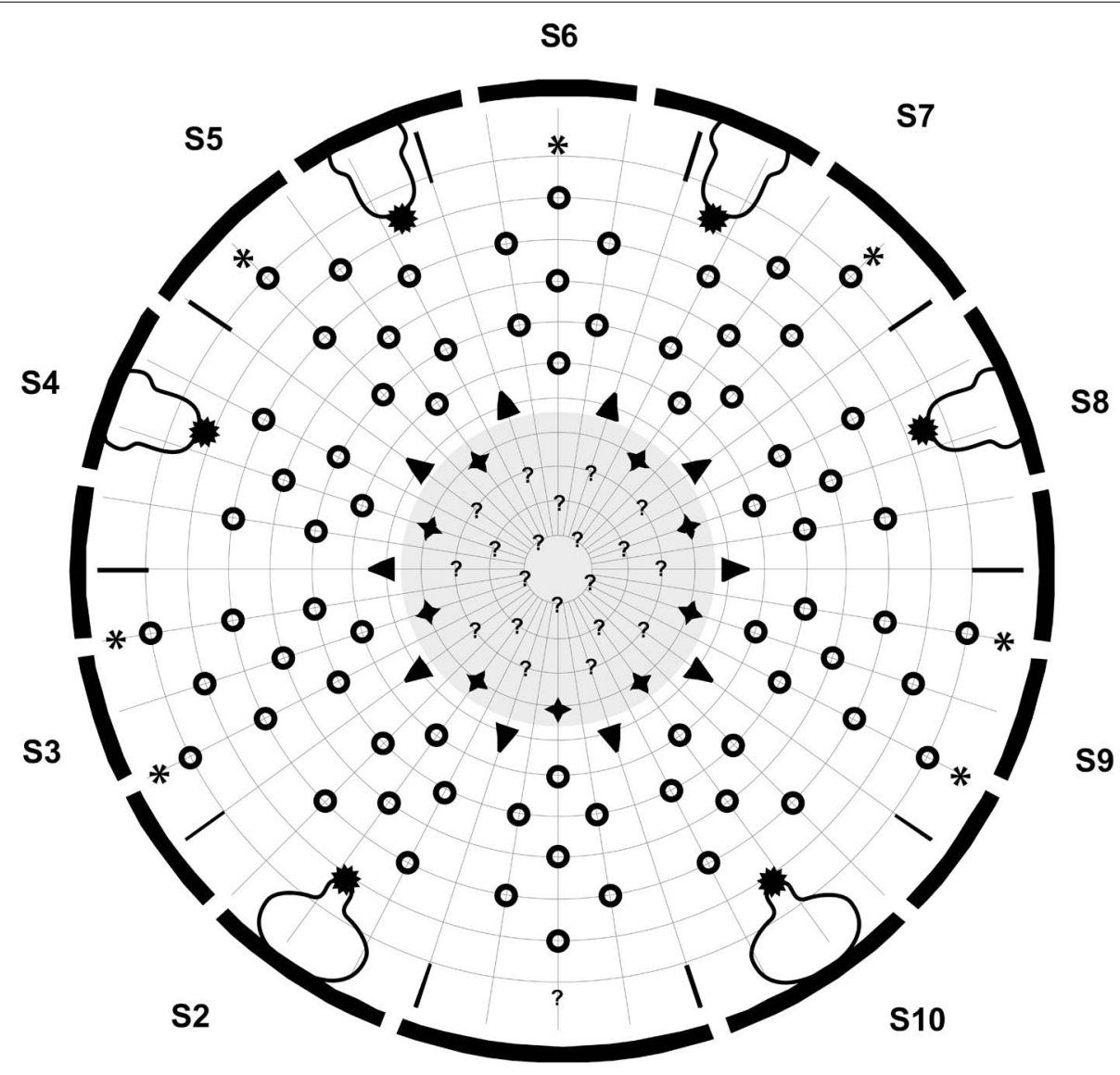

S1

Scalid and style arrangement

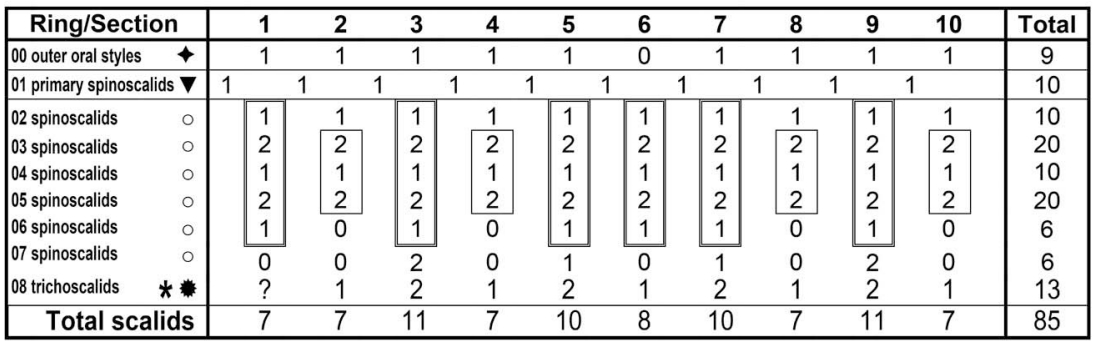

FIGURE 3 | Diagram of mouth cone (gray area), introvert, and placids in Echinoderes augustae sp. nov., showing distribution of outer oral styles, scalids, and trichoscalids. Table shows the scalid arrangement by sector; single-lined boxes mark quincunxes, double-lined boxes mark "double diamonds."

the hair areas are limited by the intersegmental joint line. The segment terminates into a pectinate fringe with well-developed fringe tips.

Segment 2 consists of a complete cuticular ring, with tubes (ca. $14 \mu \mathrm{m}$ from s.e.m.) located in lateroventral positions (Figures 2B, 4C). Pachycyclus of the anterior segment margin of regular thickness, but with a pair of notches in its posterior margin in paraventral positions (Figure 4C). Sensory spots are located in middorsal, laterodorsal (two pairs but not twin pairs), and ventromedial positions, and glandular cell outlets type 1 in ventromedial positions (Figures 2A,B, 4C). Glandular cells are arranged as an oblique cluster of light refracting granules. Sensory spots on this and the following segments are extremely small (Figure 5H), and appear as a few (ca. 8) micropapillae arranged in a circle around a central pore, that eventually has an emerging cilium. A pair of relatively large glandular cell outlets type 2 is located in subdorsal positions (Figures 2A, 4B, 5E,F). Secondary pectinate fringe present on anterior part of segment, consisting of thin, flexible fringe tips. On this and all following segments, the cuticular hairs are bracteate. They are distributed around the segment, more densely than on the preceding segment, forming a uniform covering between the secondary fringe and the 

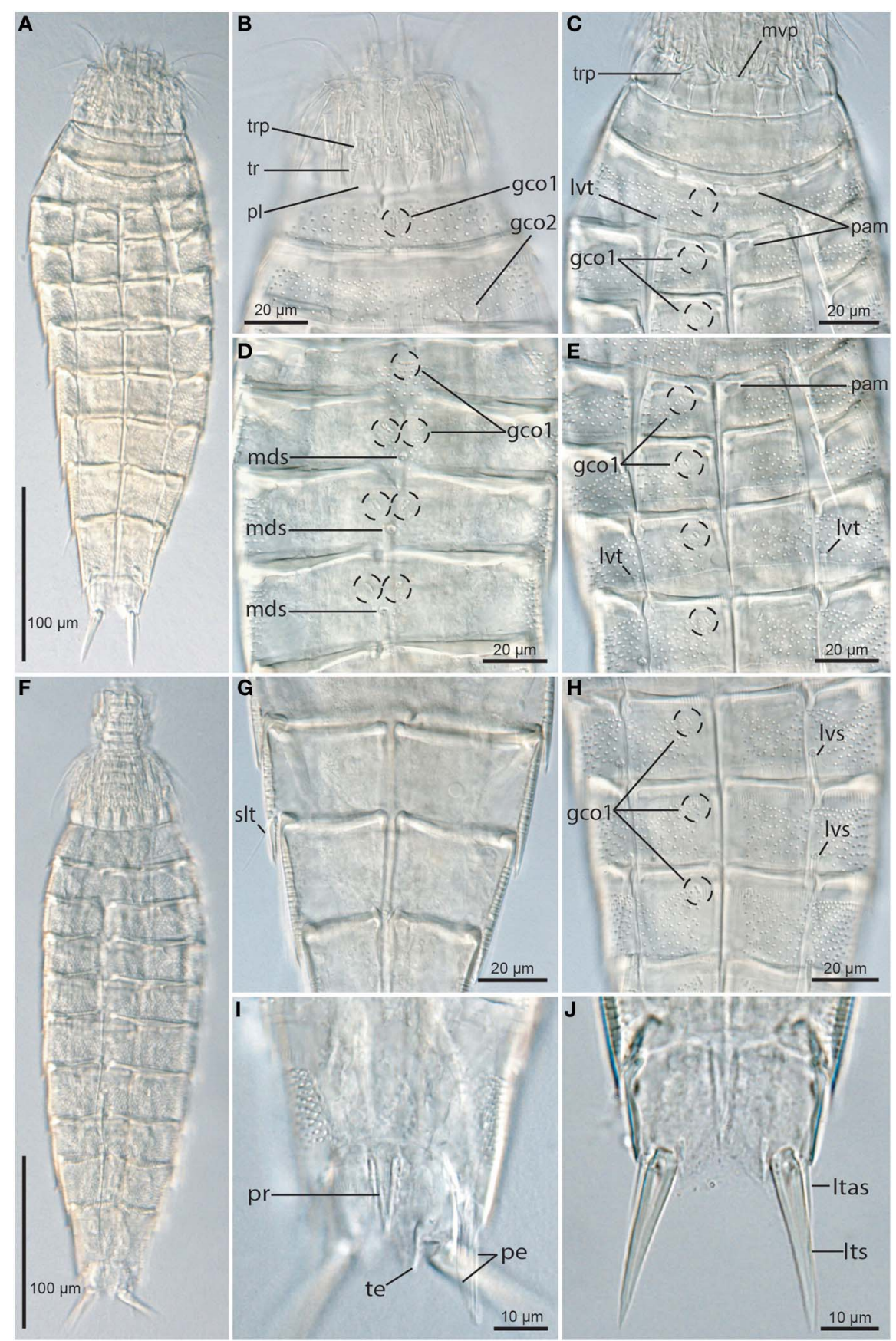

FIGURE 4 | Light micrographs showing overviews and details of trunk morphology in Echinoderes augustae sp. nov. (A-E) and (G,H) female holotype (ZMUC KIN-705); (F,I). Male paratype (ZMUC KIN-710); (J)

non-type female. (A) Ventral overview. (B) Partly retracted head, neck and segments 1 to 2, dorsal view. (C) Neck and segments 1 to 3, ventral view.

(D) Segments 3 to 6, dorsal view. (E) Segments 3 to 6, ventral view. (F) Dorsal overview. (G) Segments 8 to 9, focusing on sublateral tubule on segment 8 .
(H) Segments 6 to 8, ventral view. (I) Segment 10, dorsal view, showing middorsal protuberance, and male morphology. (J) Segment 11, ventral view, showing female morphology. Abbreviations: gco1/2, glandular cell outlet type1/2; Itas, lateral terminal accessory spine; Its, lateral terminal spine; Ivt, lateroventral tube; mds, middorsal spine; mvp, midventral placid; pam,

pachycyclus markings or loops; pe, penile spine; pl, placid; pr, protuberance; slt, sublateral tube; te, tergal extension; tr, trichoscalid; trp, trichoscalid plate. intersegmental joint line on the dorsal side of the segment, whereas hairs on the ventral side are missing in the ventromedial areas. Pectinate fringe of posterior margin as on preceding segment.
Segment 3 , and remaining segments, consisting of one tergal and two sternal plates (Figures 2A,B, 4A,C,E,F). Pachycycli of the anterior segment margin of regular thickness, but forming two small loops at the anteromedial corners of the sternal 

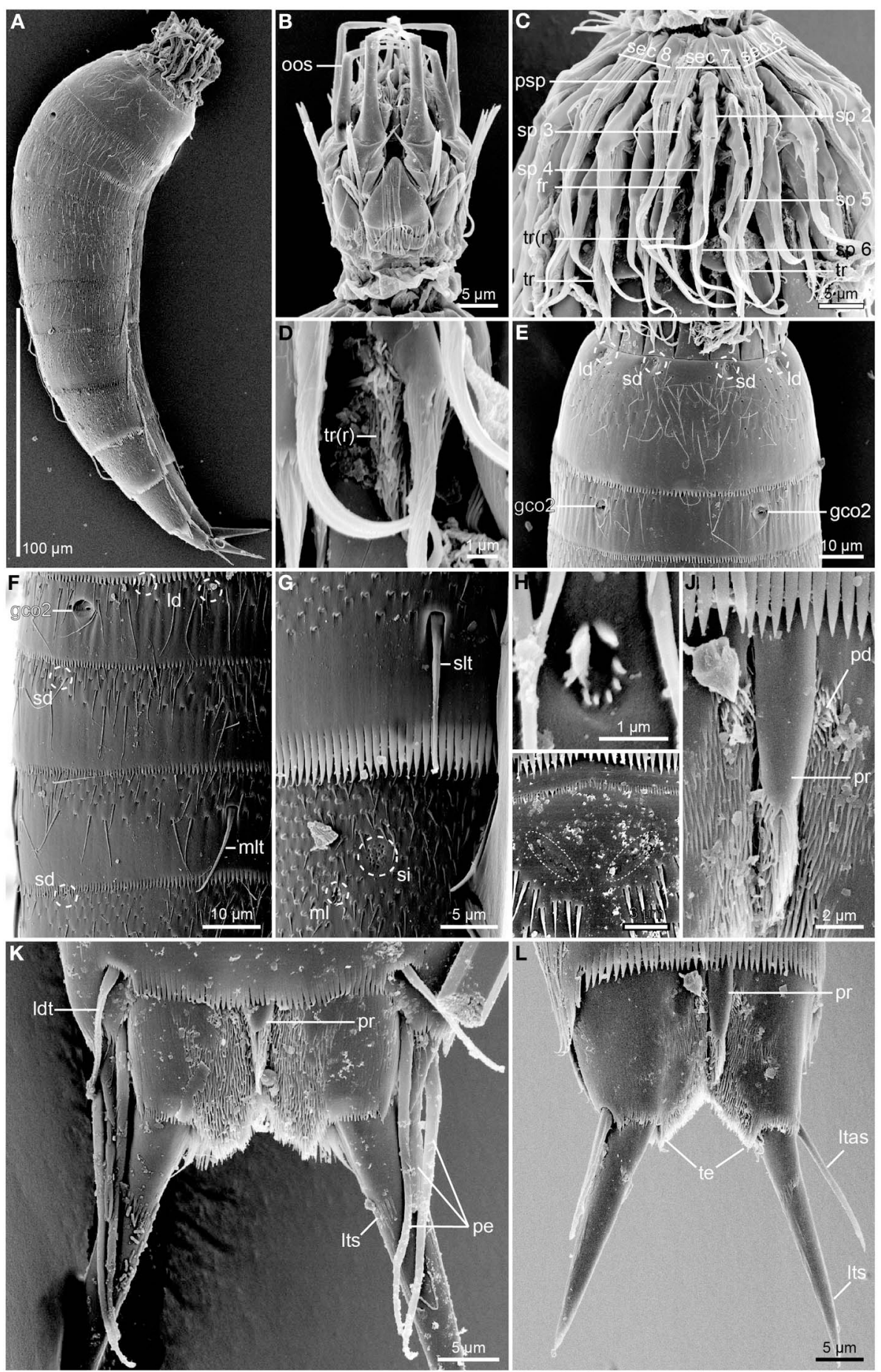

FIGURE 5 | Scanning electron micrographs of Echinoderes augustae sp. nov. (A) Female paratype (ZMUC KIN-719); (B-G). female paratype (ZMUC KIN-729); (H-I). and (K) male paratype (ZMUC KIN-725); (J,L). female paratype (ZMUC KIN-721). (A) Lateral overview. (B) Mouth cone, dorsal view, anterior to introvert section 6. (C) Introvert, showing introvert section 7 in the center. (D) Detail of introvert section 7, showing reduced trichoscalid. (E) Segments 1 to 2, dorsal view. (F) Segments 2 to 4 , lateral view. (G) Detail of segments 8 to 9 , showing sublateral tubule and sieve plate. (H) Detail showing middorsal sensory spot on segment 2. (I) Detail showing middorsal area, anterior to spine, on segment 4. Note the pore fields of the glandular cell outlets (marked with dashed line) that appear extremely indistinct in s.e.m. (J) Detail showing middorsal protuberance-like structure emerging between segments 10 and 11. (K) Segment 11, dorsal view of male. (L) Segment 11, dorsal view of female. Abbreviations: fr, fringe; gco2, glandular cell outlet type 2; Id, laterodorsal sensory spot; Idt, laterodorsal tube; Itas, lateral terminal accessory spine; Its, lateral terminal spine; $\mathrm{ml}$, midlateral sensory spot; mlt, midlateral tube; oos, outer oral styles; pd, paradorsal sensory spot; pe, penile spine; pr, protuberance; psp, primary spinoscalid; sd, subdorsal sensory spot; sec $x$, introvert sector followed by sector number; si, sieve plate; slt, sublateral tube; sp $x$, spinoscalid followed by ring number; $\operatorname{tr}(r)$, trichoscalid (reduced); te, tergal extension. 
plates (Figures 4C,E). Segment with sensory spots in subdorsal and sublateral positions, and glandular cell outlets type 1 in middorsal and ventromedial positions (Figures 4D,E, 5F). Light refracting granules in middorsal glandular cell form a transverse rod, whereas those in the ventromedial positions form obliquely arranged clusters on this and the following seven segments. Cuticular hairs evenly distributed over tergal plate, between secondary fringe and intersegmental joint line, whereas hairs on the sternal plates are arranged in rectangular patterns covering the ventrolateral and ventromedial areas. Paraventral areas are completely hairless. Posterior segment margin straight, with pectinate fringe as on preceding segment.

Segment 4 with acicular spine in middorsal position (Figures 2A, 4D), and a pair of tubes (ca. $17 \mu \mathrm{m}$ from s.e.m.) in midlateral positions (Figures $2 \mathrm{~A}, \mathbf{5 F}$ ). Sensory spots not present. Glandular cell outlets type 1 present in paradorsal and ventromedial positions (Figures 4D,E). Light refracting granules in paradorsal glandular cell form obliquely arranged clusters on this and the following five segments. All glandular cells appear very distinct in LM (Figure 4D), whereas the pore fields at their outlets are almost impossible to visualize with SEM (Figure 5I). Pachycycli, secondary fringe, pectinate fringe of posterior margin, and cuticular hairs as on preceding segment.

Segment 5 with acicular spine in middorsal position and tubes (ca. $13 \mu \mathrm{m}$ from s.e.m.) in lateroventral positions (Figures 2A,B, 4D,E). Sensory spots present in subdorsal, midlateral, and ventromedial positions. Glandular cell outlets type 1 present in paradorsal and ventromedial positions. Loop-like structures in the anteromedial corners of the sternal plates appear less distinct than on the two preceding segments (Figure 4E). Secondary fringe, pectinate fringe of posterior margin and cuticular hairs otherwise as on preceding segment.

Segments 6 and 7 are identical, with acicular spines in middorsal and lateroventral positions (Figures 2A,B, 4H). Sensory spots present in paradorsal, subdorsal, midlateral and ventromedial positions, and glandular cell outlets type 1 in paradorsal and ventromedial positions. Pachycycli without loops in the anteromedial corners of the sternal plates (Figures 4E,H). Secondary fringe, pectinate fringe of posterior margin and cuticular hairs as on preceding segment.

Segment 8 with acicular spines in middorsal and lateroventral positions and tubes (ca. $16 \mu \mathrm{m}$ from s.e.m.) in sublateral positions (Figures 2B, 4G, 5G). Sensory spots present in paradorsal and subdorsal positions only, and glandular cell outlets type 1 in paradorsal and paraventral positions. Pachycycli, secondary fringe, pectinate fringe of posterior margin, and cuticular hairs as on preceding segment.

Segment 9 without middorsal spine, but with acicular spines in lateroventral positions (Figures 2A,B). Sensory spots present in paradorsal, subdorsal, midlateral, and ventrolateral positions. A pair of minute sieve plates is located in sublateral positions (Figure 5G). Glandular cell outlets, pachycycli, secondary fringe, and pectinate fringe of posterior margin as on preceding segment, whereas fewer cuticular hairs are present in middorsal and paradorsal positions.

Segment 10 with laterodorsal tubes near posterior segment margin in males (ca. $11 \mu \mathrm{m}$ from s.e.m.) (Figures 2C, 5K); tubes are not present in females (Figure 5L). A prominent protuberance-like structure emerges in a middorsal position from the intersegmental joint between segments 10 and 11 (Figures 4I, 5J-L). The structure appears cone-shaped in LM (Figure 4I), whereas SEM shows that it is a tuft of hair-like cuticular extensions that basally are overlapped by a small, elongate cuticular plate (Figure 5J). Sensory spots present in subdorsal and ventrolateral positions, and glandular cell outlets type 1 as two middorsal ones and one pair in paraventral positions. Light refracting granules in the middorsal glandular cells form vertical clusters, whereas those of the paraventral glands are obliquely arranged. Cuticular hairs are slightly shorter than those on preceding segments, and on the tergal plate, hairs are lacking in two laterodorsal bands. The hair covering of the sternal plates is basically as on the preceding segments. The posterior segment margin of the tergal plate is straight, whereas the margins of the sternal are concave. Fringe tips in pectinate fringe of posterior margin are well-developed.

Segment 11 with lateral terminal spines (Figures 2, 4J, 5K,L). Lateral terminal spines are rather short (around 10\% of trunk length) but very stout. Females with thin and short lateral terminal accessory spines (Figures 4J, 5K), and males with three pairs of penile spines (Figures 2C,D, 4I, 5K): Dorsal and ventral penile spines are long (26-29 $\mu \mathrm{m}$ from SEM) and relatively flexible, whereas the medial one is shorter (ca. $14 \mu \mathrm{m}$ from SEM), more rigid, with a slightly swollen basal part that tapers distally. Apparently a middorsal glandular cell is present, and has its outlet through a pore field on the cuticular plate of the protuberancelike structure that emerges between segments 10 and 11 . Sensory spots are present in paradorsal (Figure 5J) and ventromedial positions, the latter near the margins of the sternal extensions. The mid- to subdorsal areas of the tergal plate are densely covered with minute filiform cuticular extensions (Figure 5K), whereas the remaining parts of the tergal plate and the sternal plates are completely smooth. Tergal extensions are rather short and triangular, whereas sternal extensions are even shorter and broadly rounded.

\section{Notes on diagnostic and taxonomic features}

Echinoderes augustae sp. nov. is easily recognized, even under a low power dissecting microscope, by its short, but really stout lateral terminal spines. Species of Echinoderes come with lateral terminal spines of varying lengths that typically lie within a range of $20-80 \%$ of the trunk length. Only few species have shorter lateral terminal spines that get down near the LTS/TL index around $10 \%$ as found in E. augustae sp. nov., but even some of these species, e.g., E. aquilonius (Higgins and Kristensen, 1988) and E. coulli (Higgins, 1977) (see Higgins, 1977; Higgins and Kristensen, 1988) still have the typical thin, needle-shaped spines that differ significantly from the stout ones found in E. augustae sp. nov.

The presence of short and stout lateral terminal spines resembling those in E. augustae sp. nov. is restricted to only six other species: E. abbreviatus (Higgins, 1983) from Belize, E. brevicaudatus (Higgins, 1966) from the Red Sea, E. cavernus (Sørensen et al., 2000) from an Australian submarine cave, E. hwiizaa (Yamasaki and Fujimoto, 2014) from Okinawa, E. obtuspinosus (Sørensen 
et al., 2012b) from the Korean West Coast and E. ulsanensis Adrianov and Malakhov, 1999 from Ulsan at the Korean East Coast (see Higgins, 1966, 1983; Adrianov and Malakhov, 1999; Sørensen et al., 2000, 2012b; Yamasaki and Fujimoto, 2014). Echinoderes augustae sp. nov. can be distinguished from these six species by its possession of midlateral tubes on segment 4 and sublateral tubes on segment 8 . None of the six species have tubes in these positions, and only E. abbreviatus has tubes on segment 8 , but these are located in lateral accessory positions. However, since especially the midlateral tubes on segment 4 can be difficult to visualize with light microscopy, some additional differential characters are convenient. Even without examining the tubes on segments 4 and 8, E. abbreviatus and E. hwiizaa are easily distinguished from E. augustae sp. nov. because E. abbreviatus has middorsal spines on segments 4,6 , and 8 only, whereas E. hwiizaa has no middorsal spines at all (Higgins, 1983; Yamasaki and Fujimoto, 2014). Echinoderes ulsanensis also stands out, because it lacks ventrolateral tubes on segment 5 and lateroventral spines on segment 6 (Adrianov and Malakhov, 1999). Of the remaining three species, E. brevicaudatus and E. cavernus have conspicuously short middorsal spines that do not extend beyond on the posterior margin of the segments where they attach (Higgins, 1966; Sørensen et al., 2000). Furthermore, none of them have glandular cell outlets type 2 on the second trunk segment, as found in subdorsal positions on segment 2 in E. augustae sp. nov. (no glandular cell outlets type 2 have been reported from E. brevicaudatus, and E. cavernus only has a single pair, located in midlateral positions on segment 9). The last species with short and stout lateral terminal spines, E. obtuspinosus, resembles E. augustae sp. nov. in several ways. The middorsal spines are still shorter, but yet closer, to the dimensions we find in E. augustae sp. nov., and in sublateral position of segment 8 , it has a glandular cell outlet type 2 , that could be confused with the attachment point of the tube found in E. augustae sp. nov. The key to distinguish E. obtuspinosus from E. augustae sp. nov. is the structures on segment 2 in the two species. Whereas E. augustae sp. nov. has glandular cell outlets type 2 in subdorsal positions only, and a pair of tubes in lateroventral positions, E. obtuspinosus has no tubes on this segment, but has instead four pairs of glandular cell outlets, situated in subdorsal, laterodorsal, sublateral, and ventrolateral positions (Sørensen et al., 2012b). These differences alone, make it easy to differentiate between the species.

Another unusual and noteworthy structure in E. augustae sp. nov. is the middorsal protuberance-like structure that emerges from the intersegmental junction between segments 10 and 11 . Such a structure is, if not unique, then at least rather rare among species of Echinoderes. A search through the literature, available specimens and unpublished photos, revealed only a single recording of something similar, namely in E. eximus (Higgins and Kristensen, 1988) (see Figure 48 in Higgins and Kristensen, 1988). Light microscopical re-examinations of paratypes of E. eximus confirmed that the species apparently has a large, tubular structure emerging middorsally between segments 10 and 11, but SEM of specimens (photos kindly provided by Jonas Thormar) could unfortunately not confirm the nature of this structure, because the examined specimens were strongly contracted so only the distal, fringed part of the structure could be observed.

\section{ECHINODERES SKIPPERAE SP. NOV. Type material}

Holotype, adult female, collected from mud on October 25, 2012, at station 085 (Figure 1), from $86 \mathrm{~m}$ depth near the rim of the continental Shelf, east of the Mississippi River Delta $\left(29^{\circ} 07^{\prime} 56.71^{\prime \prime} \mathrm{N} 088^{\circ} 42^{\prime} 27.47^{\prime \prime} \mathrm{W}\right)$, mounted in Fluoromount G, deposited at the Natural History Museum of Denmark, under accession number ZMUC KIN-730. Paratypes include 10 specimens mounted in Fluoromount G (eight specimens deposited at the Natural History Museum of Denmark under accession numbers ZMUC KIN-731 to KIN-738, and two specimens deposited at the Smithsonian Institution, National Museum of Natural History under accession numbers USNM 1231478-1231479) and four specimens mounted for SEM (accession numbers ZMUC KIN-739 to KIN-742), deposited at the Natural History Museum of Denmark. Paratypes originate from eight stations near the rim or at the slope of the continental shelf, from site 007 in the west (southeast of Corpus Christi, Texas) to site 100 in the east (southwest of Tampa, Florida). See Figure $\mathbf{1}$ for localities and Table $\mathbf{1}$ for detailed station data.

\section{Diagnosis}

Echinoderes with acicular spines in middorsal positions on segments 4, 6 and 8, and in lateroventral positions on segments 8 and 9. Tubes present in sublateral and ventrolateral positions on segment 2 , in lateroventral positions on segment 5 , in lateral accessory positions on segment 8 , and in laterodorsal positions on segment 10. Anterior margins of segments 2 to 10 , and margins of sternal plates facing the midsternal junctions of segments 3 to 10 with conspicuously well-developed pachycycli. Tergal extensions of segment 11 narrow and falciform. Males with three penile spines, females with fairly short lateral terminal accessory spines.

\section{Etymology}

The species is named after Caroline Skipper Mosgaard who kindly assisted with the examinations of the new species.

\section{Description}

Adult with head, neck and 11 trunk segments (Figures 6A,B, 7A,F, 8A,B). The segment width is nearly constant throughout the trunk, giving it an almost rectangular appearance (Figure 7F). Pachycycli of anterior margins of segments 2-10 are very strong and well-developed, which also contributes to the species' highly characteristic appearance (Figures 7A,F). For a complete overview of measures and dimensions, see Table 4. Distribution of cuticular structures, i.e., sensory spots, glandular cell outlets, spines, and tubes, is summarized in Table 5 .

The head consists of a retractable mouth cone and an introvert. The mouth cone is equipped with nine outer oral styles, each consisting of two joined units, arranged as one style anterior to each introvert sector, except the middorsal sector 6 . A fringe consisting of four to six spikes, flanked to each side by one additional spike, is located basal to each style. The posterior parts of the mouth cone and the exact arrangement of scalids on the introvert could not be examined in any of the available specimens.

The neck has 16 placids, measuring $11 \mu \mathrm{m}$ in length. Midventral placid is broadest (Figure 7C), measuring $14 \mu \mathrm{m}$ in 


\section{A}
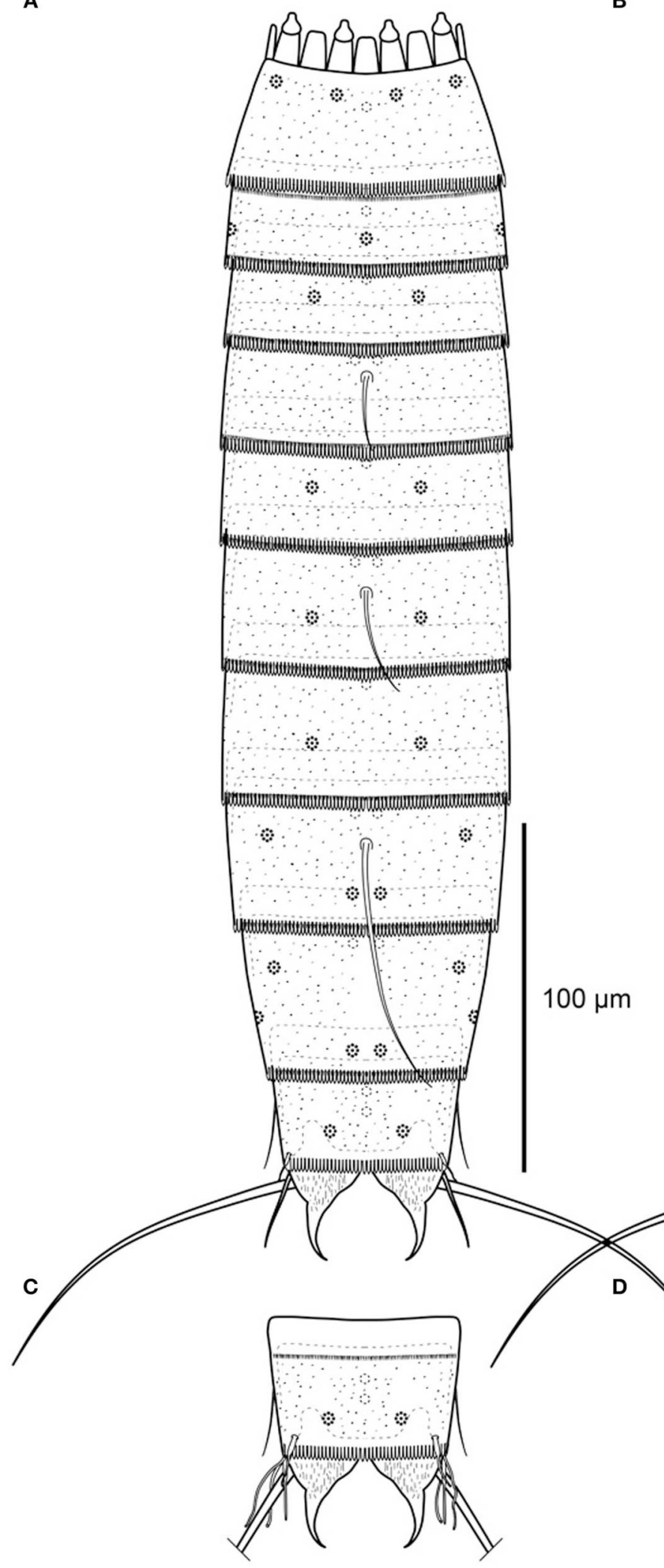

B

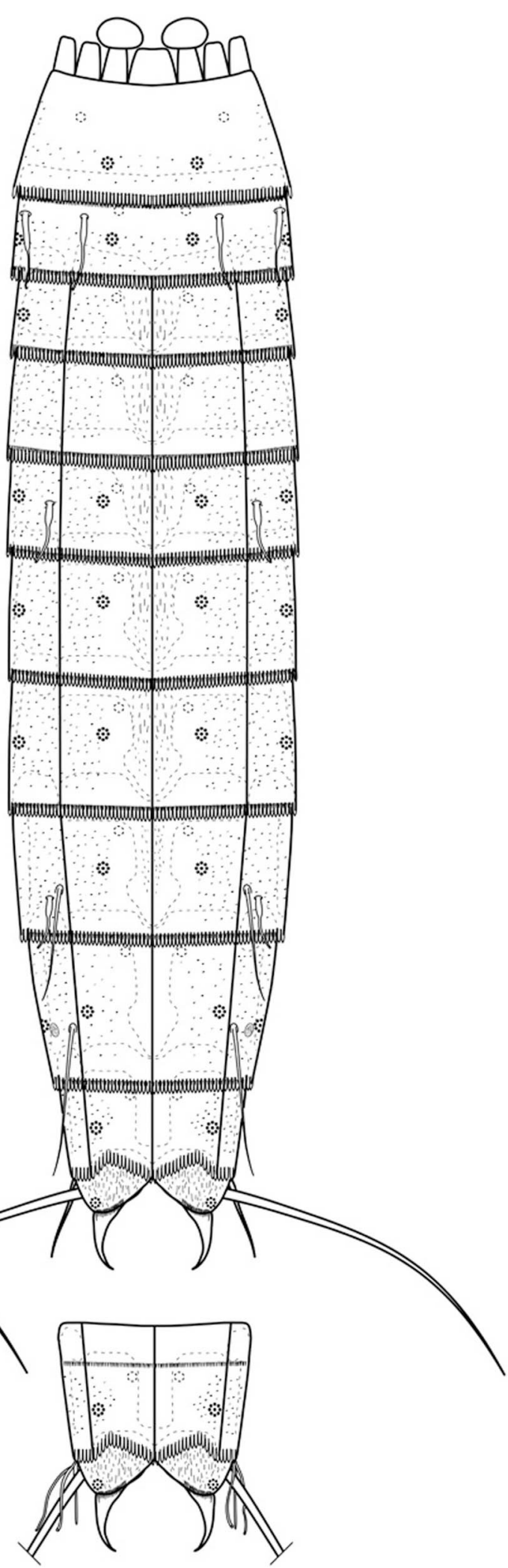

FIGURE 6 | Line art illustrations of Echinoderes skipperae sp. nov. (A) Female, dorsal view. (B) Female, ventral view. (C) Male, segments 10 to 11 , dorsal view. (D) Male, segments 10 to 11 , ventral view. 

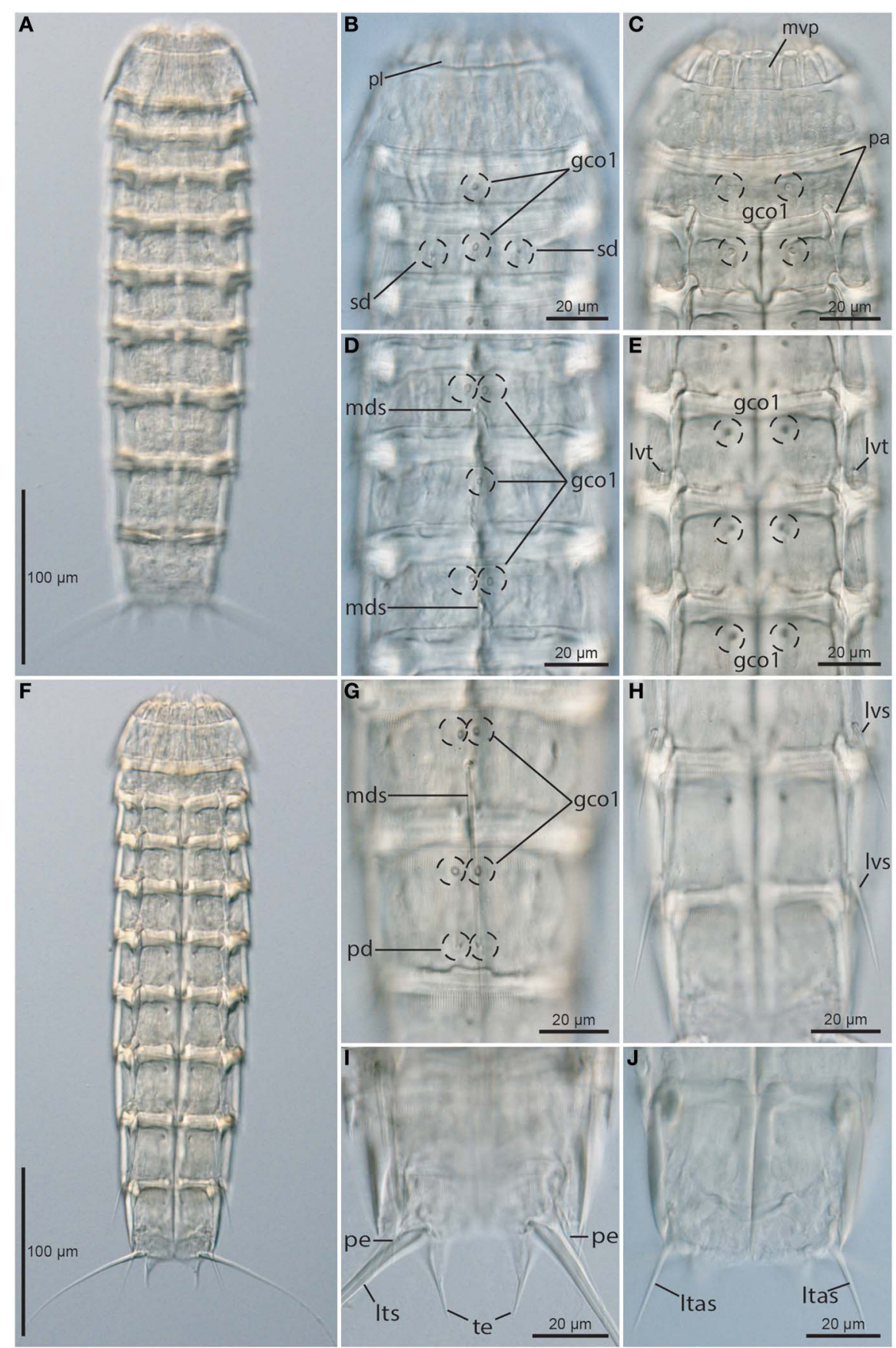

FIGURE 7 | Light micrographs showing overviews and details of trunk morphology in Echinoderes skipperae sp. nov. (A-H) and (J) female holotype (KIN-730); (I) male paratype (KIN-737). (A) Dorsal overview. (B) Neck and segments 1 to 3, dorsal view. (C) Neck and segments 1 to 3 , ventral view. (D) Segments 4 to 6, dorsal view.

(E) Segments 4 to 6, ventral view. (F) Ventral overview. (G) Segments 8 to 9, dorsal view. (H) Segments 8 to 10, ventral view. (I) Segments
10 to 11 , ventral view, showing male morphology. (J) Segments 10 to 11, ventral view, showing female morphology. Abbreviations: gco1, glandular cell outlet type1; Itas, lateral terminal accessory spine; Its, lateral terminal spine; Ivs, lateroventral spine; Ivt, lateroventral tube; mds, middorsal spine; mvp, midventral placid; pa, pachycyclus; pd, paradorsal sensory spot; pe, penile spine; pl, placid; sd, subdorsal sensory spot; te, tergal extension. width, whereas all other are narrower (Figures 7B,C), measuring $8 \mu \mathrm{m}$ in width. A total of six trichoscalids are present, located in sectors $2,4,5,7,8$, and 10 . All trichoscalids attach to trichoscalid plates.
Segment 1 consists of a complete cuticular ring (Figures 6A,B, 7B,C, 8C,D). Sensory spots are located near the anterior segment margin in subdorsal and laterodorsal positions (Figures 6A, 8C), and more posteriorly in ventromedial positions (Figure 8D). The 
Table 4 | Measurements from light microscopy of adult Echinoderes skipperae sp. nov. (in $\mu \mathrm{m}$ ), including number of measured specimens $(n)$, and standard deviation (SD).

\begin{tabular}{|c|c|c|c|c|}
\hline Character & $n$ & Range & Mean & $S D$ \\
\hline $\mathrm{TL}$ & 7 & $313-357$ & 343 & 15.30 \\
\hline MSW-7 & 8 & 55-59 & 57 & 1.36 \\
\hline MSW-7/TL & 7 & $16.0-18.2 \%$ & $16.7 \%$ & $0.76 \%$ \\
\hline SW-10 & 8 & 45-51 & 48 & 2.33 \\
\hline SW-10/TL & 7 & $12.6-16.3 \%$ & $14.0 \%$ & $1.21 \%$ \\
\hline S1 & 8 & 35-39 & 37 & 1.41 \\
\hline S2 & 8 & $26-31$ & 29 & 2.12 \\
\hline S3 & 8 & $33-38$ & 36 & 1.51 \\
\hline S4 & 8 & $35-43$ & 39 & 2.60 \\
\hline S5 & 8 & 39-49 & 43 & 3.18 \\
\hline S6 & 8 & $39-50$ & 45 & 3.42 \\
\hline S7 & 8 & $42-54$ & 50 & 3.94 \\
\hline S8 & 8 & $50-56$ & 53 & 2.55 \\
\hline S9 & 8 & $51-60$ & 55 & 2.71 \\
\hline S10 & 8 & $43-53$ & 48 & 3.64 \\
\hline S11 & 8 & 39-44 & 41 & 1.77 \\
\hline MD4 & 6 & 28-32 & 29 & 1.60 \\
\hline MD6 & 7 & $31-41$ & 34 & 3.41 \\
\hline MD8 & 7 & $50-68$ & 62 & 6.68 \\
\hline LV8 & 7 & $27-32$ & 28 & 1.72 \\
\hline LV9 & 7 & $34-44$ & 38 & 3.55 \\
\hline LTS $q$ & 6 & $102-120$ & 107 & 6.98 \\
\hline LTS $\sigma^{x}$ & 1 & 173 & N/A & $\mathrm{N} / \mathrm{A}$ \\
\hline LTASq & 6 & 28-37 & 33 & 3.72 \\
\hline LTS/TL ㅇ & 5 & $20.4-33.2 \%$ & $31.7 \%$ & $2.60 \%$ \\
\hline LTS/TL $\sigma^{7}$ & 1 & $48.5 \%$ & N/A & N/A \\
\hline
\end{tabular}

Abbreviations: MD, middorsal spine; LTAS, lateral terminal accessory spine; LTS, lateral terminal spine; $L V$, lateroventral spine; MSW-7, maximum sternal width, measured on segment 7 in this species; S, segment lengths; SW-10, standard width, always measured on segment 10; $T L$, trunk length.

sensory spots are relatively small and droplet-shaped, with a few longer micropapillae extending from the posterior margin of each sensory spot. Glandular cell outlets type 1 are present in middorsal and lateroventral positions. Cuticular hairs are present, emerging through rounded perforation sites. On the dorsal side, the hairy area almost reaches the anterior segment margin, whereas the anterior half of the segment is without hair on the ventral side. The segment terminates into a pectinate fringe, with long and thin fringe tips.

Segment 2 consists of a complete cuticular ring, with tubes (ca. $15 \mu \mathrm{m}$ from s.e.m.) located in sublateral and ventrolateral positions (Figures 6A,B, 8D,E). Pachycyclus of the anterior segment margin is conspicuously thick, broad and well-developed (Figures 7B,C). Sensory spots are located in middorsal, midlateral, and ventromedial positions (Figures 8C,D), and glandular cell outlet type 1 in middorsal and ventromedial positions, near anterior segment margin (Figures 7B,C). Sensory spots on this and all following segments are larger than those on segment 1 , and have longer micropapillae extending from the posterior margin. Secondary pectinate fringe present on anterior part of segment, consisting of thin, flexible fringe tips. On this and all following segments, the cuticular hairs are bracteate. They are distributed around the segment, more densely than on the preceding segment, forming a uniform covering between the secondary fringe and the intersegmental joint line on the dorsal side of the segment, whereas hairs on the ventral side are present on the posterior segment half only. Pectinate fringe of posterior margin as on preceding segment.

Segment 3, and remaining segments, consisting of one tergal and two sternal plates (Figures 6A,B, 7C,F). Pachycycli of the anterior segment margin and along the midsternal junction are thick, broad and well-developed (Figure 7C). Segment with sensory spots in subdorsal and sublateral positions (Figures 7B, 8E), and glandular cell outlets type 1 in middorsal and ventromedial positions (Figures 7B,C). Cuticular hairs evenly distributed over tergal plate, between secondary fringe and intersegmental joint line, only interrupted by narrow hairless midlateral patches. Hairs on sternal plates arranged in a rectangular pattern covering ventrolateral and ventromedial areas. Paraventral areas densely covered short filiform cuticular extensions. Posterior segment margin straight, with pectinate fringe as on preceding segment.

Segment 4 with acicular spine in middorsal position (Figures 6A, 7D, 8A,E). Sensory spots not present. Glandular cell outlets type 1 present in paradorsal and ventromedial positions. Pachycycli, secondary fringe, pectinate fringe of posterior margin, and cuticular hairs as on preceding segment.

Segment 5 with lateroventral tubes (ca. $16 \mu \mathrm{m}$ from s.e.m.) (Figures 6B, 7E, 8F). Sensory spots present in subdorsal and sublateral positions (Figure 8E), and, in females only, in ventromedial positions (Figure 8F). Glandular cell outlets present in middorsal and ventromedial positions (Figures 7D,E). Pachycycli, secondary fringe, pectinate fringe of posterior margin, and cuticular hairs as on preceding segment.

Segment 6 with acicular spine in middorsal position, being slightly longer than middorsal spine on segment 4 (Figures 6A, 7D, 8A). Sensory spots present in subdorsal, sublateral, and ventromedial positions (Figures 8F,G). One paratypic male had one additional subdorsal sensory spot on its right side, but this would probably be an abnormality. Glandular cell outlets type 1 present in paradorsal and ventromedial positions (Figures 7D,E). Pachycycli, secondary fringe, pectinate fringe of posterior margin, and cuticular hairs as on preceding segment.

Segment 7 without spines or tubes. Sensory spots present in subdorsal, sublateral and ventromedial positions (Figures 8F,G), and glandular cell outlets type 1 in middorsal and ventromedial positions. Pachycycli, secondary fringe, pectinate fringe of posterior margin, and cuticular hairs as on preceding segment.

Segment 8 with acicular spine in middorsal position (Figures 6A, 7G, 8A), being considerably longer than middorsal spine on segment 6 . In addition, with acicular spine in lateroventral positions and tubes (ca. $16 \mu \mathrm{m}$ from s.e.m.) in lateral accessory positions (Figures $\mathbf{6 B}, \mathbf{7 H}, \mathbf{8 F}, \mathbf{G}$ ). Sensory spots present in paradorsal, laterodorsal, and ventromedial positions (Figures $\mathbf{8 F , G}$ ), and glandular cell outlets in paradorsal (Figure 7G) and ventromedial positions. Pachycycli, secondary fringe, pectinate fringe of posterior margin, and cuticular hairs as on preceding segment. 


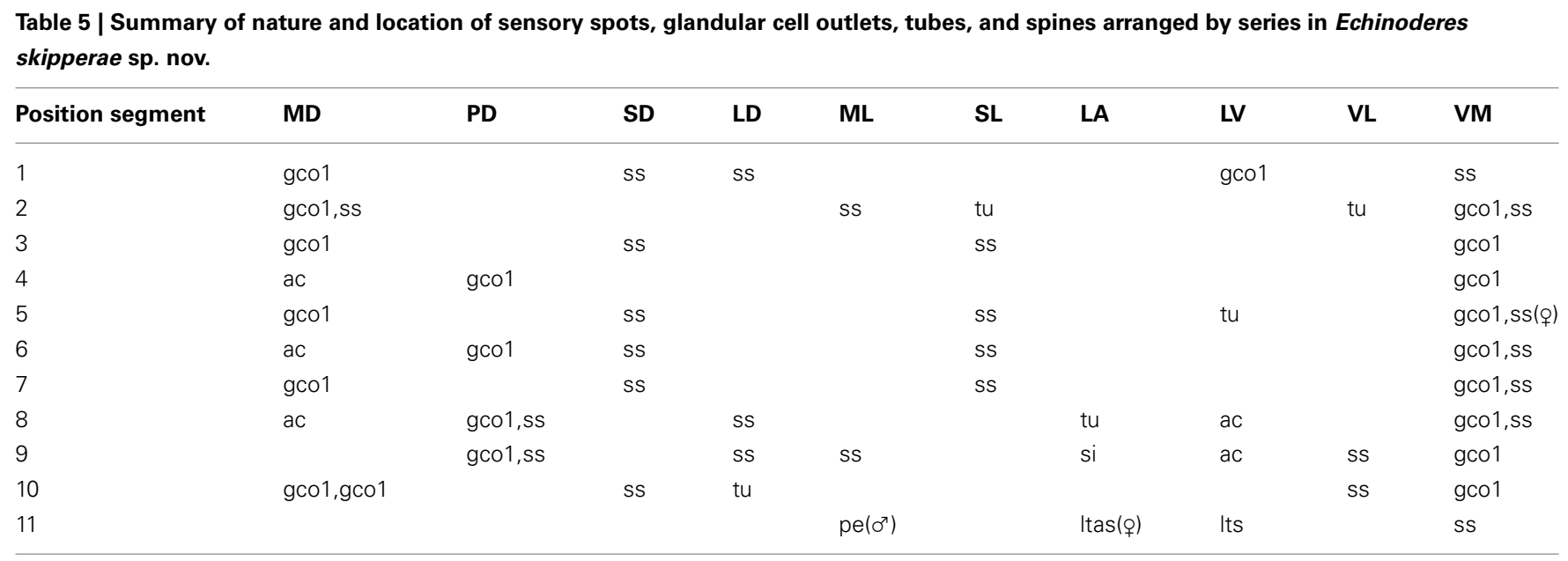

Abbreviations: $L A$, lateral accessory; $L D$, Laterodorsal; $L V$, lateroventral; $M D$, middorsal; $M L$, midlateral; $P D$, paradorsal; $S D$, subdorsal; $S L$, sublateral; $V L$, ventrolateral; VM, ventromedial; ac, acicular spine; (q), female condition of sexual dimorphic character; gcol, glandular cell outlet type 1; Itas, lateral terminal accessory spine; Its, lateral terminal spine; $\left(0^{\prime}\right)$, male condition of sexual dimorphic character; pe, penile spines; si, sieve plate; ss, sensory spot; tu, tube.

Segment 9 with acicular spines in lateroventral positions (Figures 6B, 7H, 8H). Sensory spots present in paradorsal (posterior on segment) (Figures 7G, 8I), laterodorsal (anterior on segment), midlateral and ventrolateral (medial on segment) positions. A pair of minute sieve plates is located in lateral accessory positions (Figure 8H). Glandular cell outlets, pachycycli, secondary fringe, and pectinate fringe of posterior margin as on preceding segment, whereas fewer cuticular hairs are present in middorsal and paradorsal positions. The filiform cuticular extensions in the paraventral areas are reduced to tiny irregularities in the cuticular surface.

Segment 10 with laterodorsal tubes near posterior segment margin (Figures 6A,C, 8H,I). Tubes in females (ca. $8 \mu \mathrm{m}$ from s.e.m.) are considerably short than those in males (ca. $15 \mu \mathrm{m}$ from s.e.m.). Sensory spots present in subdorsal (Figures 8I,J) and ventrolateral positions, and glandular cell outlets type 1 as two middorsal ones and one pair in ventromedial positions. Cuticular hairs are mostly present on the lateral sides of the tergal plate, and in an area between the subdorsal sensory spots (Figures 8I,J). On the sternal plates, a few cuticular hairs are present, mostly in ventrolateral positions, slightly extending into the ventromedial areas. The filiform cuticular extensions are only visible as small, longitudinal wrinkles in the paraventral areas. The posterior segment margin of the tergal plate is straight, whereas the margins of the sternal plates are concave. Fringe tips in pectinate fringe of posterior margin are slightly longer and stronger than those on the preceding segment.

Segment 11 with lateral terminal spines (Figures 6A,B, 7F,I, $\mathbf{8 I}, \mathbf{J})$. Lateral terminal spines appear to be longer in males than in females (see Table 4), but data from additional male specimens would be desirable to confirm this. Females with lateral terminal accessory spines (Figures 6A,B, 7J, 8J), and males with three pairs of penile spines (Figures 6C,D, 7I, 8I): dorsal and ventral penile spines are long, flexible and slender, medial one is shorter, thicker, and conically tapering. Sensory spots are present in ventromedial positions only, almost on the margin of the sternal extensions. Cuticular hairs not present, but tergal and sternal plates are densely covered with filiform cuticular extensions. Tergal plate projects beyond sternal plates and terminates into two slender, falciform tergal extensions (Figures 7I, 8I,J). Sternal extensions of sternal plates are short and broadly rounded.

\section{Notes on diagnostic and taxonomic features}

The new species is very easily distinguished from all other congeners by its conspicuously thick and well-developed pachycycli at the anterior segment margins that almost resemble a series of belts around the trunk. This character makes it possible to recognize the species, even at low magnification under a dissecting scope. Also the falciform tergal extensions are highly characteristic and would help to distinguish this species from most other echinoderids.

The spine pattern on the dorsal side, with middorsal spines on segments 4,6 , and 8 , is the second most common among species of Echinoderes (see, e.g., Adrianov and Malakhov, 1999). However, the pattern of the lateral spine series, namely lateroventral tubes on segment 5 , and lateroventral spines on segments 8 and 9 only, is rather rare and shared only with Echinoderes caribiensis (Kirsteuer, 1964) (see Kirsteuer, 1964). However, E. skipperae nov. sp. has in addition a lateral accessory tube on segment 8 . Such a tube is missing in E. caribiensis, which makes the lateral spine series in both species unique. Also the arrangement of tubes on segment 2, namely a pair in sublateral and ventrolateral positions, is unique for the new species. Having only a single pair of tubes on segment 2, located in ventrolateral positions, is extremely common in Echinoderes, and is found in almost half of the species in the genus (see, e.g., Adrianov and Malakhov, 1999). In addition to these, there are several species showing various combinations of tubes in ventrolateral and other positions, e.g., E. kanni and E. adrianovi with tubes on segment 2 in subdorsal and ventrolateral positions (see Thormar and Sørensen, 2010; Herranz et al., 2014), E. newcaledoniensis, E. peterseni and E. hispanicus, with tubes in laterodorsal, sublateral, and ventrolateral positions (see Higgins, 1967; Higgins and Kristensen, 1988; Pardos et al., 1998), E. intermedius with tubes in subdorsal, laterodorsal and 


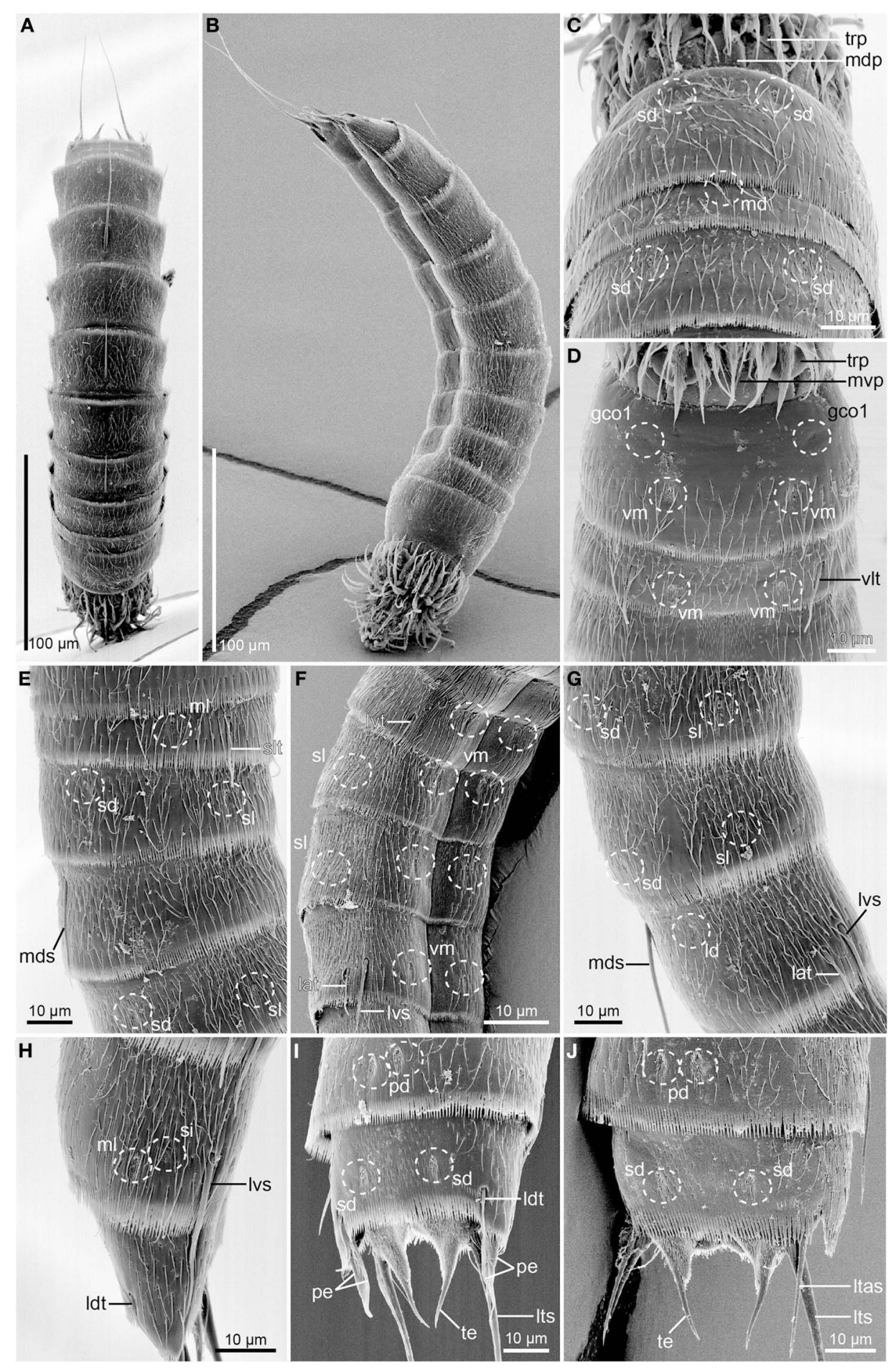

FIGURE 8 | Scanning electron micrographs of Echinoderes skipperae sp. nov. (A-E) and (G-I) male paratype (KIN-742); (F,J). female paratype (KIN-740). (A) Dorsal overview. (B) Lateral overview. (C) Segments 1 to 3, dorsal view. (D) Segments 1 to 3, ventral view. (E) Segments 2 to 4, lateral view. (F) Segments 5 to 8, lateroventral view. (G) Segments 6 to 8, lateral view. (H) Segments 9 to 10, lateral view. (I) Segments 9 to 11, dorsal view of male. (J) Segments 9 to 11, dorsal view of female. Abbreviations: gco1, glandular cell outlet type1; lat, lateral accessory tube; Id, laterodorsal sensory spot; Itas, lateral terminal accessory spine; Its, lateral terminal spine; Ivs, lateroventral spine; $\mathrm{md}$, middorsal sensory spot; mdp, middorsal placid; mds, middorsal spine; $\mathrm{ml}$, midlateral sensory spot; mvp, midventral placid; pd, paradorsal sensory spot; pe, penile spine; sd, subdorsal sensory spot; si, sieve plate; sl, sublateral sensory spot; slt, sublateral tube; te, tergal extension; trp, trichoscalid plate; vit, ventrolateral tube; $\mathrm{vm}$, ventromedial sensory spot. 
sublateral positions (see Sørensen, 2006), and finally E. capitatus, E. cantabricus, E. isabelae, and E. ajax with four pairs of tubes, namely in subdorsal, laterodorsal, sublateral, and ventrolateral positions (see Zelinka, 1928; Nebelsick, 1992; Pardos et al., 1998; Ga Ordóñez et al., 2008; Sørensen, 2014).

Hence, in conclusion, due to the strongly developed pachycycli, conspicuously shaped tergal extensions, and unique spine and tubule patterns, E. skipperae sp. nov. cannot be confused with any other species.

\section{Distribution of the two new species and their associated kinorhynch fauna}

Echinoderes augustae nov. sp. and E. skipperae nov. sp. were recorded from ten and eight stations, respectively. Of these stations, the species co-occurred at two stations, namely St. 075 (2012) and St. 085 (2012) (see Figure 1 and Table 1). Both stations are situated close to the Mississippi River Delta. Besides this, both species co-occurred with numerous additional kinorhynch species. A total of six species of Echinoderes were recorded together with E. augustae nov. sp., of which the five definitely are new to science, whereas the last one could not be examined properly. In addition, it co-occurred together with two undescribed species of Condyloderes and Centroderes, respectively.

Three of the yet undescribed Echinoderes species also cooccurred with E. skipperae nov. sp., and one additional new species of the genus was recorded with E. skipperae nov. sp. at St. 007 (2010). Furthermore, a new species of Sphenoderes and Pycnophyes co-occurred with the species at St. 007 (2010) and St. 100 (2010), respectively.

\section{CONCLUSIONS}

This study of Gulf of Mexico kinorhynchs has revealed that the Gulf holds a great, yet undescribed, kinorhynch fauna along the continental shelf, and this diversity will most probably turn out to be even greater when the studies are extended to include habitats closer to the coast, further down the slope, or in the deep-sea habitats in the central basin of the Gulf. The first two species described from the habitats on the continental shelf or the upper slope appear to be widely distributed, and occur at several stations from Texas to Florida. Echinoderes skipperae sp. nov. shows the greatest distribution, with about $1.400 \mathrm{~km} / 869$ miles from its western- to its easternmost occurrence (measured along the rim of the shelf), whereas the corresponding distance for E. augustae sp. nov. is $1.070 \mathrm{~km} / 664$ miles. This suggests that both species probably could be recorded at any locality near the upper part of the slope, and continuous populations along the shelf/slope area probably exist for both species. Most of the recorded specimens occurred near the slope, but still on the uppermost plateau of the continental shelf, at depths ranging from $56 \mathrm{~m}$ to around $100 \mathrm{~m}$. However, they were also recorded from deeper localities, down to $178 \mathrm{~m}$ at the West Florida Escarpment (E. augustae sp. nov., station 163 on Figure 1) and to $361 \mathrm{~m}$ on the Louisiana (station 83 on Figure 1), suggesting that the species are not necessarily restricted to the more shallow waters on the shelf. We expect that the following contributions about the Gulf of Mexico kinorhynch fauna will reveal a more detailed picture of the species diversity, and distributional patterns for each species.

\section{ACKNOWLEDGMENTS}

This research was made possible by a grant from BP/The Gulf of Mexico Research Initiative. The authors thank Dr. Frank Romano (Jacksonville State University- JSU) for his contribution to this research, and thank the students and technicians at Troy University (TU) and JSU for help with sediment collection and laboratory work. Additionally, we thank the researchers at the NMFS/NOAA Pascagoula lab for their help with sediment collection and Dr. Steve Ramroop (TU) for Figure 1. Special thanks go to Caroline Skipper Mosgaard and Augusta Bork Larsen for their help examining and describing the two new species.

\section{REFERENCES}

Adrianov, A. V., and Malakhov, V. V. (1999). Cephalorhyncha of the World Ocean. Moscow: KMK Scientific Press.

Burgess, R. (2001). An improved protocol for separating meiofauna from sediments using colloidal silica sols. Mar. Ecol. Prog. Ser. 214, 161-165. doi: $10.3354 /$ meps 214161

Chitwood, B. G. (1951). Echinoderella steineri new species (Scolecida, Echinodera). Texas J. Sci. 3, 113-114.

Gáardóñez, D., Pardos, F., and Benito, J. (2008). Three new Echinoderes (Kinorhyncha, Cyclorhagida) from North Spain, with new evolutionary aspects in the genus. Zool. Anz. 247, 95-111. doi: 10.1016/j.jcz.2007.07.001

Herranz, M., and Pardos, F. (2013). Fissuroderes sorenseni sp. nov., and Meristoderes boylei sp. nov.: first Atlantic recording of two rare kinorhynch genera, with new identification keys. Zool. Anz. 253, 93-111. doi: 10.1016/j.jcz.2013. 09.005

Herranz, M., Sánchez, N., Pardos, F., and Higgins, R. P. (2014). New Kinorhyncha from Florida coastal waters. Helgol. Mar. Res. 68, 59-87. doi: 10.1007/s10152013-0369-9

Herranz, M., Thormar, J., Benito, J., Sánchez, N., and Pardos, F. (2012). Meristoderes gen. nov., a new kinorhynch genus, with the description of two new species and their implications for echinoderid phylogeny (Kinorhyncha: Cyclorhagida, Echinoderidae). Zool. Anz. 251, 161-179. doi: 10.1016/j.jcz.2011.08.004

Higgins, R. P. (1964a). Redescription of the kinorhynch Echinoderes remanei (Blake, 1930) Karling, 1954. Trans. Am. Microsc. Soc. 83, 243-247. doi: 10.2307/3224573

Higgins, R. P. (1964b). Three new kinorhynchs from the North Carolina Coast. Bull. Mar. Sci. Gulf Caribbean 14, 479-493.

Higgins, R. P. (1965). The homalorhagid Kinorhyncha of Northeastern U.S. Coastal Waters. Trans. Am. Microsc. Soc. 84, 65-72. doi: 10.2307/3224541

Higgins, R. P. (1966). Faunistic studies in the Red Sea (in winter 1961-1962). Zool. Jb Syst. 93, 118-126.

Higgins, R. P. (1967). Two Kinorhyncha of New-Caledonia. Expédition Française sur Recifs Coralliens de la Nouvelle Caledonia 2, 75-90.

Higgins, R. P. (1977). Two new species of Echinoderes (Kinorhyncha) from South Carolina. Trans. Am. Microsc. Soc. 96. 340-354. doi: 10.2307/3225864

Higgins, R. P. (1983). The Atlantic barrier reef ecosystem at Carrie Bow Cay, Belize, II: Kinorhyncha. Smithson. Contrib. Mar. Sci. 18, 1-131. doi: 10.5479/si.01960768.18.1

Higgins, R. P. (1990). Zelinkaderidae, a new family of cyclorhagid Kinorhyncha. Smithson. Contr. Zool. 500, 1-26.

Higgins, R. P., and Fleeger, J. W. (1980). Seasonal changes in the population structure of Echinoderes coulli (Kinorhyncha). Est. Coast. Mar. Sci. 10, 495-505. doi: 10.1016/S0302-3524(80)80071-5

Higgins, R. P., and Kristensen, R. M. (1988). Kinorhyncha from Disko Island, West Greenland. Smithson. Contrib. Zool. 458, 1-56. doi: 10.5479/si.00810282.458

ICZN, (1999). International Code of Zoological Nomenclature. 4th Edn. London: The Natural History Museum.

Kirsteuer, E. (1964). Zur Kenntnis der Kinorhynchen Venezuelas. Zool. Anz. 173, 388-393.

Landers, S., Romano, F. A. III., Stewart, P. M., and Ramroop, S. (2012). A multi-year survey of meiofaunal abundance from the Northern Gulf of Mexico continental shelf and slope. Gulf Mex. Sci. 2012, 20-29.

Lundbye, H., Rho, H. S., and Sørensen, M. V. (2011). Echinoderes rex n. sp. (Kinorhyncha: Cyclorhagida) — the largest Echinoderes species found so far. Sci. Mar. 75, 41-51. doi: 10.3989/scimar.2011.75n1041 
Nebelsick, M. (1992). Ultrastructural investigations of three taxonomic characters in the trunk region of Echinoderes capitatus (Kinorhyncha, Cyclorhagida). Zool. Scr. 21, 335-345. doi: 10.1111/j.1463-6409.1992.tb00335.x

Pardos, F., Higgins, R. P., and Benito, J. (1998). Two new Echinoderes (Kinorhyncha, Cyclorhagida) including a reevaluation of kinorhynch taxonomic characters. Zool. Anz. 237, 195-208.

Sánchez, N., Herranz, M., Benito, J., and Pardos, F. (2012). Kinorhyncha from the Iberian Peninsula: new data from the first intensive sampling campaigns. Zootaxa 3402, 24-44.

Sánchez, N., Herranz, M., Benito, J., and Pardos, F. (2014). Pycnophyes almansae sp. nov. and Pycnophyes lageria sp. nov., two new homalorhagid kinorhynchs (Kinorhyncha, Homalorhagida) from the Iberian Peninsula, with special focus on introvert features. Mar. Biol. Res. 10, 17-36. doi: 10.1080/17451000.2013. 793804

Sánchez, N., Pardos, F., Herranz, M., and Benito, J. (2011). Pycnophyes dolichurus sp. nov. and $P$. aulacodes sp. nov. (Kinorhyncha, Homalorhagida, Pycnophyidae), two new kinorhynchs from Spain with a reevaluation of homalorhagid taxonomic characters. Helgol. Mar. Res. 65, 319-334. doi: 10.1007/ s10152-010-0226-Z

Sánchez, N., Rho, H. S., Min, W., Kim, D., and Sørensen, M. V. (2013). Four new species of Pycnophyes (Kinorhyncha: Homalorhagida) from Korea and the East China Sea. Sci. Mar. 77, 353-380. doi: 10.3989/scimar.03769.15A

Shirley, T. C. (2009). "Kinorhyncha of the Gulf of Mexico," in Gulf of Mexico Origin, Waters, and Biota, Vol. 1, Biodiversity, eds D. L. Felder and D. K. Camp (Corpus Christi: Texas A and M University Press), 1129-1132.

Sørensen, M. V. (2006). New kinorhynchs from Panama with a discussion of some phylogenetically significant cuticular structures. Meiofauna Mar. 15, 51-77. doi: 10.1016/j.ode.2007.11.002

Sørensen, M. V. (2007). A new species of Antygomonas (Kinorhyncha: Cyclorhagida) from the Atlantic coast of Florida, USA. Cah. Biol. Mar. 48, $155-168$.

Sørensen, M. V. (2014). First account of echinoderid kinorhynchs from Brazil, with the description of three new species. Mar. Biodiv. doi: 10.1007/s12526-0130181-4. [Epub ahead of print].

Sørensen, M. V., Heiner, I., and Ziemer, O. (2005). A new species of Echinoderes from Florida (Kinorhyncha: Cyclorhagida). Proc. Biol. Soc. Wash. 118, 499-508. doi: 10.2988/0006-324X(2005)118[499:ANSOEF]2.0.CO;2

Sørensen, M. V., Heiner, I., Ziemer, O., and Neuhaus, B. (2007). Tubulideres seminoli gen. et sp. nov., and Zelinkaderes brightae sp. nov. (Kinorhyncha, Cyclorhagida) from Florida. Helgol. Mar. Res. 61, 247-265. doi: 10.1007/s10152-007-0073-8

Sørensen, M. V., Herranz, M., Rho, H. S., Min, W., Yamasaki, H., Sánchez, N., et al. (2012a). On the genus Dracoderes Higgins \& Shirayama, 1990 (Kinorhyncha: Cyclorhagida) with a redescription of its type species, D. abei, and a description of a new species from Spain. Mar. Biol. Res. 8, 210-232. doi: $10.1080 / 17451000.2011 .615328$

Sørensen, M. V., Jørgensen, A., and Boesgaard, T. M. (2000). A new Echinoderes (Kinorhyncha: Cyclorhagida) from a submarine cave in New South Wales, Australia. Cah. Biol. Mar. 41, 167-179.
Sørensen, M. V., Pardos, F., Herranz, M., and Rho, H. S. (2010a). New data on the genus Paracentrophyes (Homalorhagida, Kinorhyncha), with the description of a new species from the West Pacific. Open Zool. J. 3, 42-59. doi: 10.2174/1874336601003010042

Sørensen, M. V., Rho, H. S., and Kim, D. (2010b) A new species of the rare genus Sphenoderes (Cyclorhagida, Kinorhyncha), with differential notes on S. indicus Higgins, 1969. Mar. Biol. Res. 6, 472-484. doi: 10.1080/17451000903334702

Sørensen, M. V., Rho, H. S., and Kim, D. (2010c) A new species of Condyloderes (Cyclorhagida, Kinorhyncha) from Korea. Zool. Sci. 27, 234-242. doi: 10.2108/zsj.27.234

Sørensen, M. V., Rho, H. S., Min, W., Kim, D., and Chang, C. Y. (2012b). An exploration of Echinoderes (Kinorhyncha: Cyclorhagida) in Korean and neighboring waters, with the description of four new species and a redescription of $E$. tchefouensis Lou, 1934. Zootaxa 3368, 161-196.

Sørensen, M. V., Rho, H. S., Min, W., Kim, D., and Chang, C. Y. (2013). Occurrence of the newly described kinorhynch genus Meristoderes (Cyclorhagida: Echinoderidae) in Korea, with the description of four new species. Helgoland Mar. Res. 67, 291-319. doi: 10.1007/s10152-012-0323-2

Thomsen, V. G., Rho, H. S., Kim, D., and Sørensen, M. V. (2013). A new species of Dracoderes (Kinorhyncha: Dracoderidae) from Korea provides further support for a dracoderid-homalorhagid relationship. Zootaxa 3682, 133-142. doi: 10.11646/zootaxa.3682.1.6

Thormar, J., and Sørensen, M. V. (2010). Two new species of Echinoderes (Kinorhyncha: Cyclorhagida) from the Solomon Islands. Meiofauna Mar. 18, 67-96.

Yamasaki, H., and Fujimoto, S. (2014). Two new species in the Echinoderes coulli group (Echinoderidae, Cyclorhagida, Kinorhyncha) from the Ryukyu Islands, Japan. Zookeys 382, 27-52. doi: 10.3897/zookeys.382.6761

Zelinka, K. (1928). Monographie der Echinodera. Leipzig: Verlag Wilhelm Engelmann.

Conflict of Interest Statement: The authors declare that the research was conducted in the absence of any commercial or financial relationships that could be construed as a potential conflict of interest.

Received: 25 March 2014; paper pending published: 03 April 2014; accepted: 30 April 2014; published online: 27 May 2014.

Citation: Sørensen MV and Landers SC (2014) Two new species of Echinoderes (Kinorhyncha: Cyclorhagida) from the Gulf of Mexico. Front. Mar. Sci. 1:8. doi: 10.3389/fmars.2014.00008

This article was submitted to Marine Systematics and Taxonomy, a section of the journal Frontiers in Marine Science.

Copyright (c) 2014 Sørensen and Landers. This is an open-access article distributed under the terms of the Creative Commons Attribution License (CC BY). The use, distribution or reproduction in other forums is permitted, provided the original author(s) or licensor are credited and that the original publication in this journal is cited, in accordance with accepted academic practice. No use, distribution or reproduction is permitted which does not comply with these terms. 